\title{
WATER-RESOURCES ACTIVITIES IN NEW YORK FISCAL YEAR 1989
}

Compiled by Mary P. Marshall

U.S. GEOLOGICAL SURVEY

Open-File Report 90-376

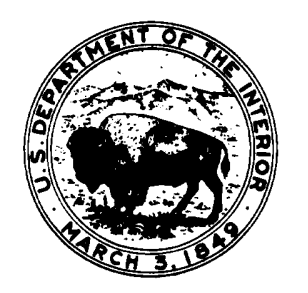

Albany, New York

1991 
DEPARTMENT OF THE INTERIOR

MANUEL LUJAN, JR., Secretary

U. S. GEOLOGICAL SURVEY

Dallas L. Peck, Director

For additional information write to:

U. S. Geological Survey

P. O. Box 1669

Albany, NY 12201

(518) $472-3107$
Copies of this report may be purchased from:

U.S. Geological Survey

Books \& Open-File Reports Section

Federal Center, Bldg. 810

Box 25425,

Denver, CO. 80225 


\section{CONTENTS}

Introduction $\mathbf{1}$

U.S. Geological Survey programs 1

Water Resources Division's mission and program 2

Types of funding 3

New York District 4

Projects in 19896

ALBANY OfFICE PROJECTS

001 Surface-water stations 7

002 Ground-water stations 8

003 Water-quality stations 9

005 National Trends Network 10

007 Water-use data 11

045 Flood investigations 13

046 PCB transport in upper Hudson River 14

114 Baseline water-quality assessment of selected aquifers 16

152 Biological response to changes in stream chemistry 18

165 Sorptive and transport characteristics of PCB congeners 19

167 Westchester ground-water study 20

171 Glacial aquifers northern Hudson-Mohawk lowlands 21

173 Hydrologic budget and aquatic changes in Woods Lake 22

175 Saltwater movement in Hudson River estuary 23

178 Evaluation of scour at bridges in New York 25

181 Water flow paths in two limed watersheds 26

ITHACA OfFICE PROJECTS

140 Channel-roughness characteristics 27

161 Effects of instream impoundment, Monroe County 28

164 Hydrogeology of the Niagara Falls area 29

169 Subsurface transport under conventional and conservation tillage 30

170 Landfill leachate in a Phragmites wetland 31

176 Tug Hill aquifer 32 
184 Contributing areas from contaminant sources at Cortland 33

187 Hydrogeology of tributary valleys in Chenango County 34

LONG IsLAND OfFICE PROJECTS

125 Hydrologic models of ground-water flow system 35

132 Hydrologic atlas 36

147 Saltwater in Nassau County 38

148 Water-quality appraisal 39

153 Selected topics in ground-water geochemistry 41

155 Pumping centers on Long Island $\mathbf{4 2}$

159 Contaminant transport in two aquifers 43

160 Cross-sectional analysis of ground-water flow patterns 44

162 Computer applications 45

163 Base-flow separation 46

172 Advective transport and saltwater influences on the north fork 47

174 Well-siting methodology 48

177 Analysis of aquifer vulnerability 49

182 Modifications of recharge structures 50

183 Migration of contaminants by advective transport 51

New York District staff $\mathbf{5 2}$

Reports published or released, May 1988-September 198953

Cooperating agencies in $1989 \quad 56$

Where to obtain U. S. Geological Survey publications $\mathbf{5 8}$

Where to obtain additional information on U.S. Geological Survey Programs

\section{ILLUSTRATION}

Figure 1.-Organization chart and list of office addresses 5 


\section{INTRODUCTION}

The U.S. Geological Survey (USGS) was established by an act of Congress on March 3, 1879, to provide a permanent Federal Agency to conduct the systematic and scientific "classification of the public lands, and examination of the geological structure, mineral resources, and products of national domain." An integral part of that original mission includes publishing and disseminating the earth-science information needed to understand, to plan the use of, and to manage the Nation's energy, land, mineral, and water resources.

\section{U.S. Geological Survey Programs}

Since 1879, the research and fact-finding role of the USGS has grown and been modified to meet the changing needs of the Nation it serves. As part of that evolution, the USGS has become the Federal Government's largest earth-science research agency, the Nation's largest civilian mapmaking agency, the primary source of data on the Nation's surface- and ground-water resources, and the employer of the largest number of professional earth scientists. Today's programs serve a diversity of needs and users. Programs include:

- Conducting detailed assessments of the energy and mineral potential of the Nation's land and offshore areas.

- Investigating and issuing warnings of earthquakes, volcanic eruptions, landslides, and other geologic and hydrologic hazards.

- Conducting research on the geologic structure of the Nation.

- Studying the geologic features, structure, processes, and history of the other planets of our solar system.

- Conducting topographic surveys of the Nation and preparing topographic and thematic maps and related cartographic products.

- Developing and producing digital cartographic data bases and products.

- Collecting data on a routine basis to determine the quantity, quality, and use of surface water and ground water.

- Conducting water-resource appraisals to describe the consequences of alternative plans for developing land and water resources.

- Conducting research in hydraulics and hydrology, and coordinating all Federal water-data acquisition.

Using remotely sensed data to develop new cartographic, geologic, and hydrologic research techniques for natural resources planning and management. 
- Providing earth-science information through an extensive publications program and a network of public access points.

Along with its continuing commitment to meet the growing and changing earthscience needs of the Nation, the USGS remains dedicated to its original mission to collect, analyze, interpret, publish, and disseminate information about the natural resources of the Nation-providing "Earth Science in the public Service."

\section{Water Resources Division's Mission and Program}

The mission of the Water Resources Division is to provide the hydrologic information and understanding needed for the optimum use and management of the Nation's water resources for the overall benefit of the people of the United States. This is accomplished, in large part, through cooperation with other Federal and non-Federal agencies by:

- Collecting, on a systematic basis, data needed for the continuing determination and evaluation of the quantity, quality, and use of the Nation's water resources.

- Conducting analytical and interpretive water-resource appraisals describing the occurrence, availability, and the physical, chemical, and biological characteristics of surface water and ground water.

- Conducting supportive basic and problem-oriented research in hydraulics, hydrology, and related fields of science to improve the scientific basis for investigations and measurement techniques and to understand hydrologic systems sufficiently well to quantitatively predict their response to stress, either natural or manmade.

- Disseminating the water data and the results of these investigations and research through reports, maps, computerized information services, and other forms of public releases.

- Coordinating the activities of Federal agencies in the acquisition of water data for streams, lakes, reservoirs, estuaries, and ground water.

- Providing scientific and technical assistance in hydrologic fields to other Federal, State, and local agencies, to licensees of the Federal Power Commission, and to international agencies on behalf of the Department of State. 


\section{Types of Funding}

The diagram below shows the percentage of the investigations for fiscal year 1989 in each of the broad categories of collection of hydrologic data, areal appraisals and interpretive studies, and research projects:

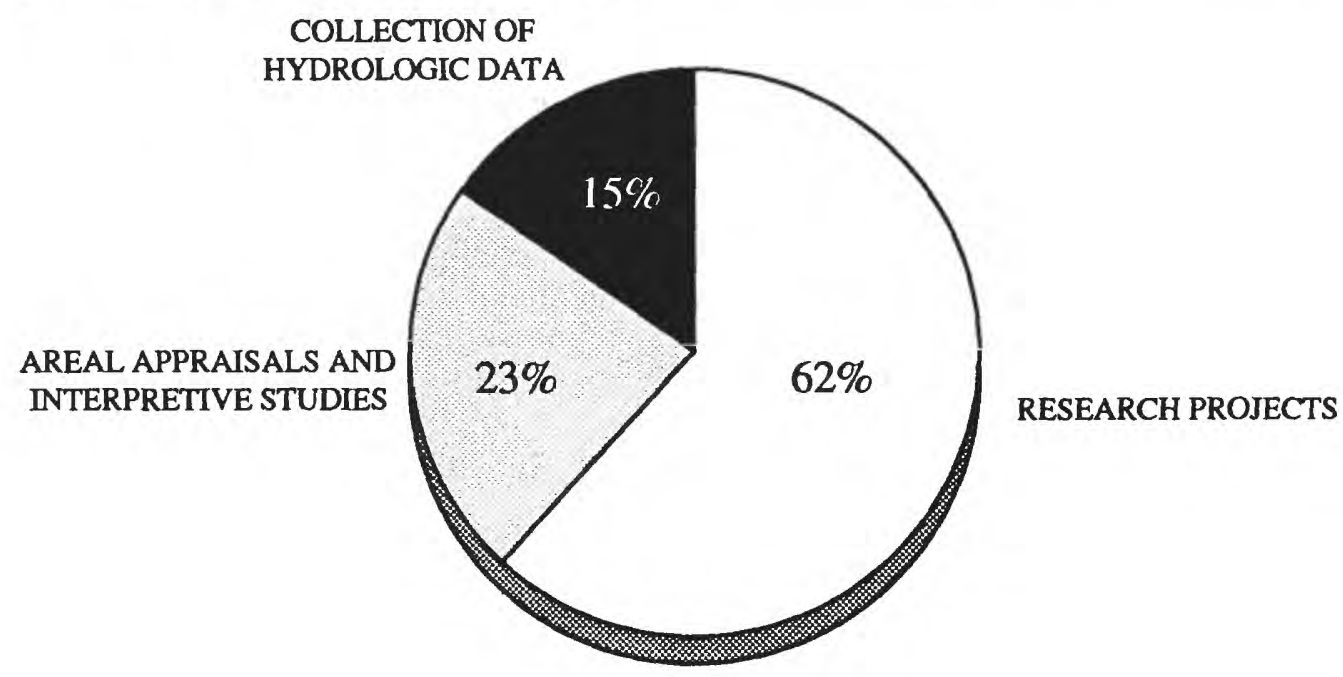

These investigations are directed toward obtaining the information needed by managers and planners for the solution or alleviation of water problems in New York. The investigations are supported by funds provided by State and local units of government and federal funds from the U.S. Geological Survey and other federal agencies. About 70 percent of the federal funds contributed by the U.S. Geological Survey are used to match, on a 50-50 basis, the funds contributed by the State and other local units of government. In fiscal year 1989, the financial support for these programs in New York was about $\$ 7.5$ million, which was distributed as follows:

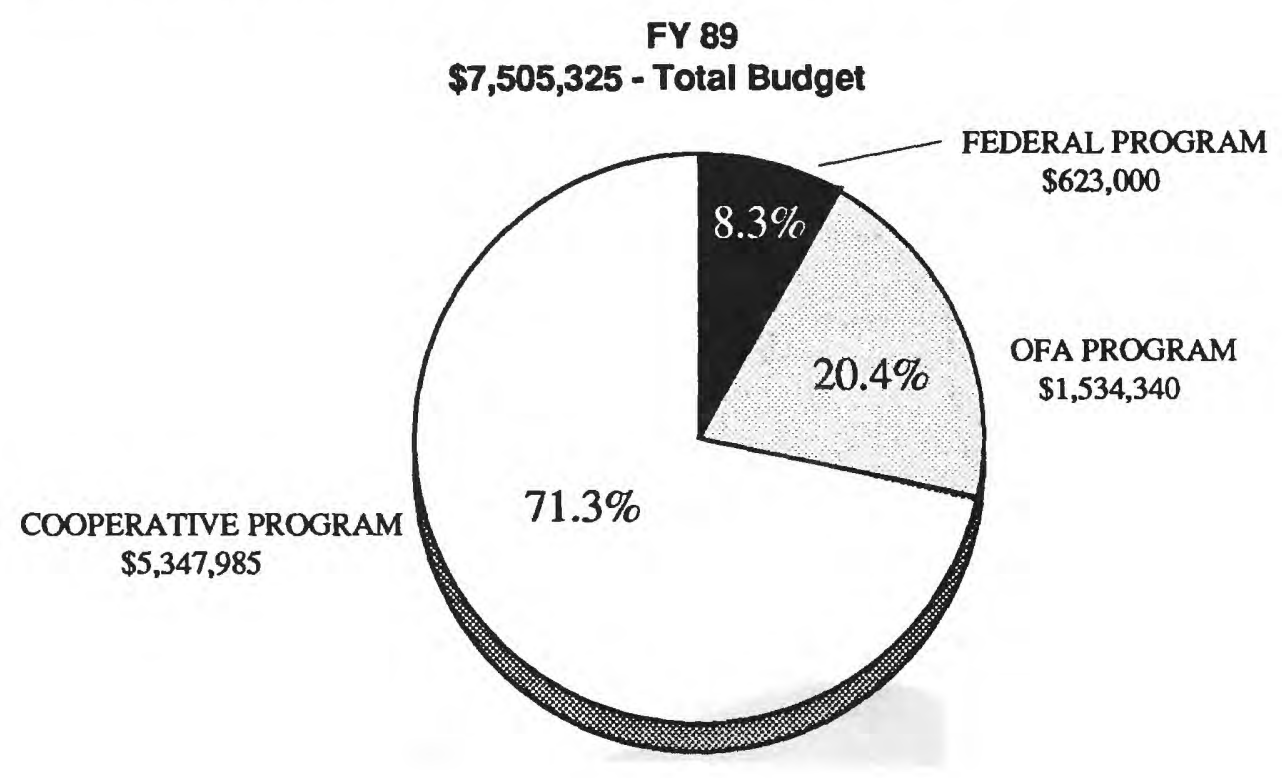


The following sections describe the water-resources investigations conducted by the U.S. Geological Survey in New York in fiscal 1989; many of these studies will continue into 1990 or longer. The Geological Survey began its water-resources studies in New York State in 1895 with a stream-gaging program in the Catskill Mountain region and entered its first cooperative program, with the Office of the State Engineer, in 1900. The Survey has maintained a District office in Albany since 1910 to direct its water investigations within the State and has maintained a subdistrict office on Long Island since 1932 to study and monitor the ground-water situation in this area of increasing urbanization. The Survey also maintains subdistrict offices in Ithaca and Albany to collect and interpret data from western and eastern New York, respectively, and maintains a field station in Potsdam to collect records in the northernmost part of the State.

The staff of the New York District numbers about 100. The professional hydrologists represent a variety of scientific and technical backgrounds that include engineering, chemistry, geology, mathematics, physics, biology, and soil science. The hydrologists are assisted by experienced engineering and hydrologic technicians who provide support service in the collection and analysis of field data, and by specialists in computer, publication, and administrative services.

The office addresses and organization chart are given on page 5; the office locations are shown in the map below. A partial list of staff members is given on page 58 .

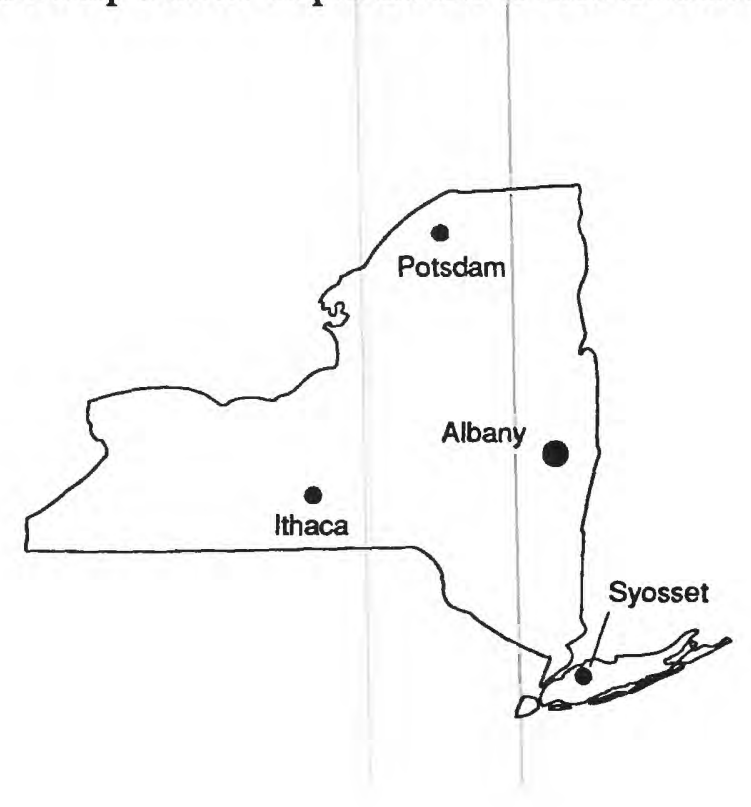




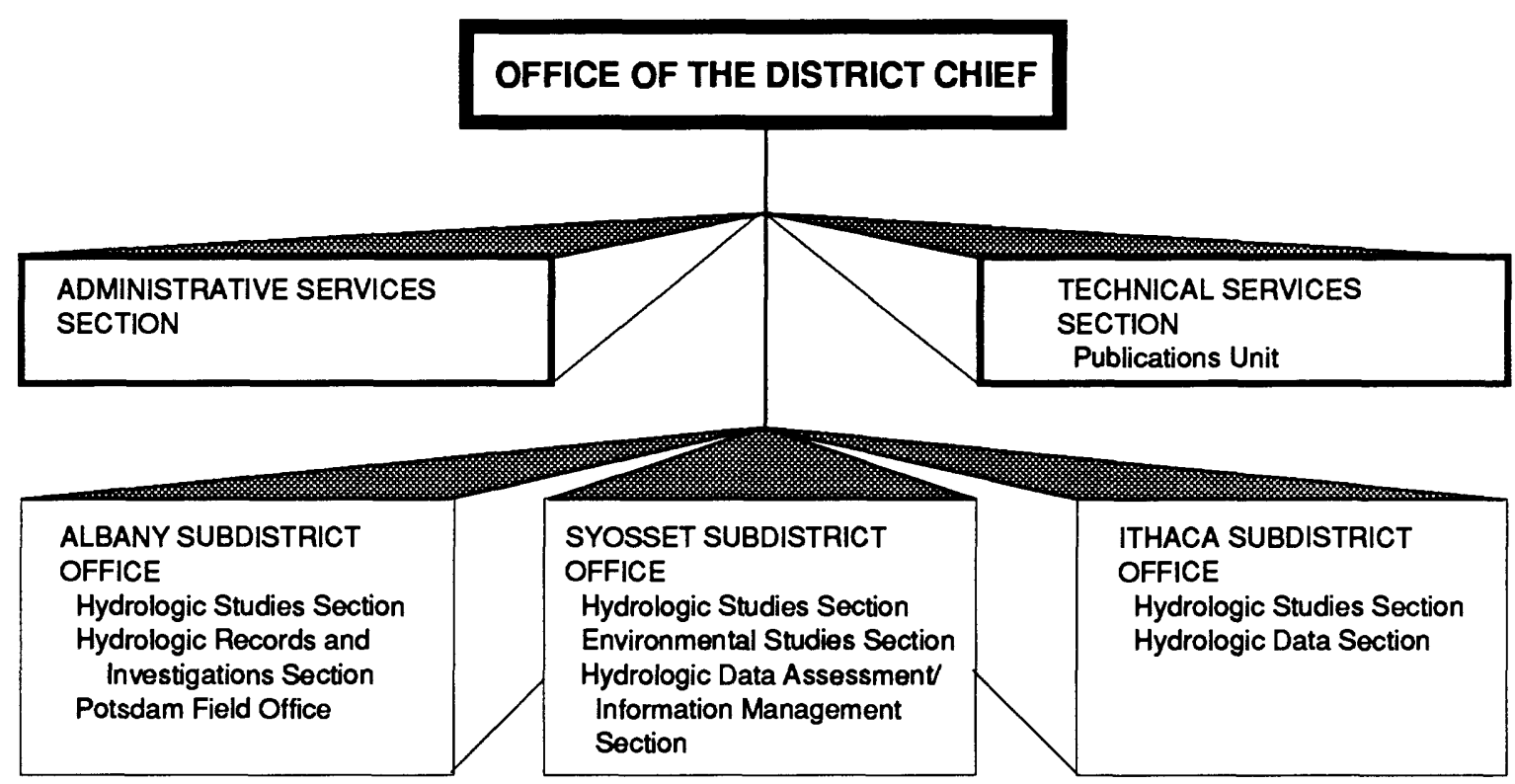

\section{NEW YORK DISTRICT OFFICE ADDRESSES}

Inquiries regarding projects described in this section may be directed to the District Office or Subdistrict Office in which the work originated.
District Office
(518) $472-3107$

Albany Subdistrict Office

(518) $472-3107$

Ithaca Subdistrict Office

(607) $272-8722$

Long Island Subdistrict Office

(516) $938-8830$

Potsdam Field Headquarters

(315) $265-4410$
U.S. Geological Survey Water Resources Division James T. Foley Courthouse P.O. Box 1669

Albany, N.Y. 12201

James T. Foley Courthouse P.O. Box 1669

Albany, N.Y. 12201

521 West Seneca Street Ithaca, N.Y. 14850

5 Aerial Way Syosset, N.Y. 11791

Route 2 Sandfordville, N.Y. 13676

Figure 1.-New York District organization chart with office addresses.

(List of staff members is on page 58.) 


\title{
PROJECTS IN FISCAL YEAR 1989
}

Projects conducted by the New York District during fiscal 1989 are described on the following pages. They are grouped by office location and are given in numerical order by project number. (See list on pp. iii-iv.)

\author{
Albany........ 7 \\ Ithaca....... 27 \\ Syosset ...... 35
}


Period of project: Continuous since June 1898

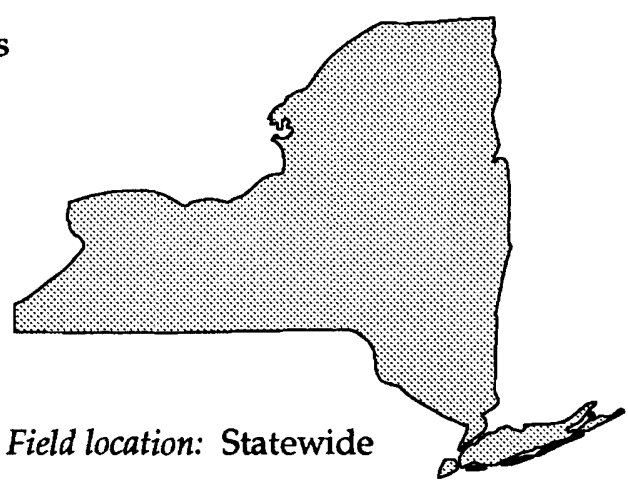

Project leader: George Gravlee
Cooperating agencies: New York State Department of Environmental Conservation; U.S. Army Corps of Engineers; City of New York, Department of Environmental Protection; Nassau County Department of Public Works; Suffolk County Department of Environmental Control; Suffolk County Water Authority; National Weather Service; New York Power Authority; Hudson River-Black River Regulating District; Westchester County Department of Public Works

Problem: Surface-water information is needed for surveillance, planning, design, hazard warning, operation, and management in waterrelated fields such as water supply, hydroelectric power, flood control, irrigation, bridge and culvert design, wildlife management, pollution abatement, flood-plain management, and water-resources development. An appropriate data base is required to provide this information.

Objective: (1) To collect surface-water data for such purposes as (a) assessment of water resources, (b) operation of reservoirs or industries, (c) forecasting of stage or discharge, (d) pollution control and disposal of wastes, (e) discharge data to accompany water-quality measurements, (f) compact and legal require- ments, and (g) research or special studies. (2) To collect data to define the properties and trends of water in streams, lakes, estuaries, etc., for use in planning and design.

Approach: To use standard methods of data collection as described in the series "Techniques of Water Resources Investigations of the United States Geological Survey" and to use partial-record gaging instead of completerecord gaging where possible.

Progress and significant results: Operation of the network proceeded successfully. Equipment upgrading at gaging stations continues. New stations, planned through cooperative efforts, will be installed in water year 1990 .

Plans for next year: To upgrade gaging equipment as the budget permits and to reactivate and construct specific sites for project activities.

Completed reports:

U.S. Geological Survey, Water resources data New York: U.S. Geological Survey Water-Data Report, v. 1, Eastern New York excluding Long Island; v. 2, Long Island; v. 3, Western New York. (Published annually.) 
Period of project: Continuous since July 1934

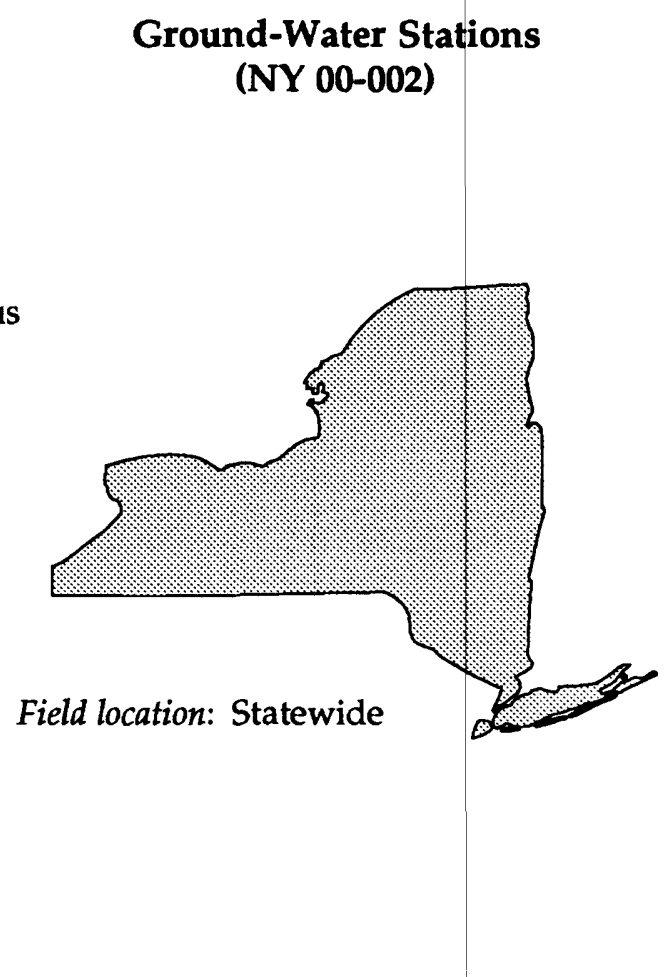

Project leader: John H. Williams
Cooperating agencies: New York State Department of Environmental Conservation; Suffolk County Department of Environmental Control; Suffolk County Water Authority; Nassau County Department of Public Works

Problem: Long-term information on groundwater levels is needed to evaluate the effects of climatic and manmade stresses on the aquifer systems of New York.

Objectives: (1) To provide long-term waterlevel records so that the response of aquifer systems to climatic and manmade stresses can be evaluated and potential problems can be defined early to allow for proper planning and management. (2) To provide long-term waterlevel records with which short-term information from ground-water investigations can be compared.

Approach: Collect long-term water-level records at selected observation wells that are representative of the hydrologic conditions in the State.

Progress and significant results: Collection and compilation of ground-water levels at 50 upstate and 225 Long Island wells continued. Ground-water level records were published in the annual data report.

Plans for next year: To continue to collect, compile, and publish water-level records and evaluate the observation-well network.

\section{Completed reports:}

U.S. Geological Survey, Water resources data New York: U.S. Geological Survey Water Data Report, v. 1, Eastern New York excluding Long Island, v. 2, Long Island, v. 3, Western New York. (Published annually.) 


\section{Water-Quality Stations}

(NY 00-003)
Period of project: Continuous since June 1906

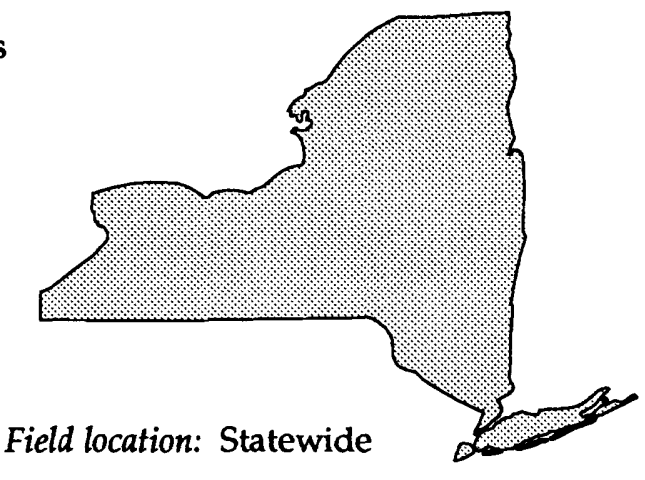

Project Leader: Robert J. Rogers
Cooperating agencies: New York State Department of Environmental Conservation; Suffolk County Water Authority; Nassau County Department of Public Works; City of New York, Department of Environmental Protection

Problem: Water-resources planning and waterquality assessment require statewide and nationwide levels of information of the chemical and physical qualities of surface water and ground water.

Objective: To develop a statewide and nationwide bank of water-quality data for Federal, State, and local planning and to provide these data where needed to support other projects within New York.

Approach: To maintain and operate a statewide network of water-quality stations (some of which are part of a nationwide network) to provide data on concentrations, loads, and time trends of chemical constituents of surface water and ground water, and to provide water-temperature data for management purposes.
Progress and significant results: Water-quality samples were collected at 13 NASQAN (National Stream Quality Accounting Network) stations, one Hydrologic Benchmark Network station, 53 additional surface-water stations, and two ground-water stations for chemical analysis. Continuous water-temperature records were collected at 13 stations.

Plans for next year: Water-quality samples will continue to be collected at surface-water stations. Forty ground-water stations are planned for the network in 1990. Water-temperature records will be collected at the same stations as of 1989. Data from 1989 will be published in the annual water-resources data report.

Completed reports:

U.S. Geological Survey, Water resources data New York: U.S. Geological Survey Water Data Report, v. 1, Eastern New York excluding Long Island; v. 2, Long Island; v. 3, Western New York. (Published annually.) 


\section{National Trends Network (NTN) for Monitoring Atmospheric Deposition (NY 83-005)}

Period of project: Continuous since June 1983

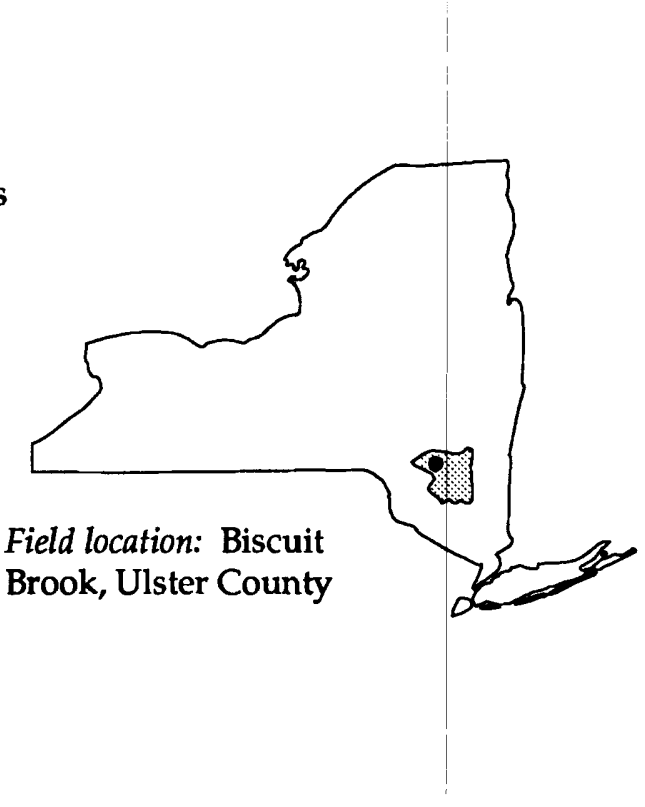

Project leader: Peter S. Murdoch
Cooperating agency: Federally funded

Problem: A nationwide long-term monitoring network needs to be developed and maintained to detect and measure chemical trends in atmospheric deposition. Prior to the National Atmospheric Deposition/NTN program, no national monitoring of deposition chemistry was being done. In addition, longterm trends in stream chemistry need to be established in headwater watersheds.

Objective: (1) To document weekly variations in atmospheric deposition and collect wet deposition for analysis of elements and compounds that contribute to the chemical composition of surface waters. (2) To determine the relation between stream chemistry and discharge, and to monitor long-term trends in stream chemistry.

Approach: (1) To (a) set up monitoring stations as part of the National Trends Network; (b) maintain stations, make onsite measurements, process samples, and submit them to a laboratory; (c) verify data retrievals, and (d) prepare a final report. (2) To (a) collect long- and short-term samples of streamwater from Biscuit Brook, (b) continuously monitor stream stage, and (c) conduct longitudinal chemistry and flow profiles.

Progress and significant results: Monitoring continued. Data were transferred to national data bases. Interaction was established between NTN and Albany office staff to correct errors in precipitation data. Investigation of stream chemistry and flow characteristics upstream of the Biscuit Brook gage was begun, and five sampling runs were completed. Data suggest no clear long-term trends in stream sulfate or nitrate concentrations.

Plans for next year: To continue operation of the small-watershed study with emphasis on episodic stormflows, soil-water contributions, and longitudinal profiles of stream chemistry, and complete journal articles on nitrate movement and chemical budgets in Biscuit Brook.

\section{Completed reports:}

Murdoch, P. S., Chemical budgets and stream chemistry dynamics of a headwater stream in the Catskill Mountains, New York, October 1, 1983 through September 30, 1985: U. S. Geological Survey Water-Resources Investigations Report 88-4035 (in press). 
Period of project: Continuous since January 1979

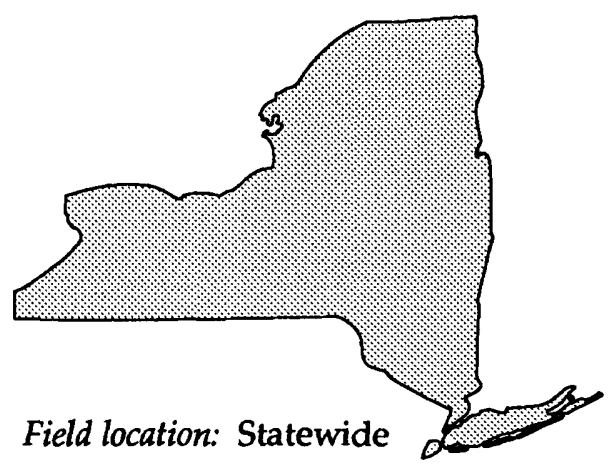

Project leader:

Deborah S. Snavely Lumia
Cooperatingagency: New YorkState Department of Environmental Conservation

Problem: The demand for water in New York State is unevenly distributed, and little information is available on water use. Because increasing competition for local supplies could lead to shortages, information is needed on present uses, how use may vary, and how the availability and nature of the resources vary with demand. These are addressed by two studies that are intended to (a) collect data on withdrawals in specified water-use categories for New York State, and (b) examine the interaction of water use, availability, and waste sites in Dutchess County.

Objectives: (1) To determine what agencies collect data on water use in specified categories. (2) To collect and compile water-use data for input to SWUDS (Site-specific WaterUse Data System) and AWUDS (Aggregated Water-Use Data System). (3) To develop a system whereby the agencies that collect the data can transmit periodic updates to the main data bank. (4) To make the data available through computer processing and reports. (5) To evaluate the relation between water use and availability in Dutchess County, and possible sources of ground-water contamination. (6) To store detailed water-use data from the
Great Lakes basin.

Approach: (1) New York State agencies will furnish water-use data for specific categories of use. (2) Local agencies and organizations in specific counties will also supply water-use data. (3) A system of data transmittal will be established among State and local agencies, and the USGS. (4) The water-use data will be used to update SWUDS and AWUDS. (5) Periodic water-use reports will be written.

Progress and significant results: A new wateruse data base for New York State was designed. A fact sheet on water use in New York was published. Date bases, tables and maps for the Dutchess County study were refined.

Plans for next year: (1) To complete the first draft of the Dutchess County report and the annotated outline of the statewide water-use data report. (2) To assist the New York State Department of Environmental Conservation in the development of a site-specific water-use data base in New York. (3) To begin reviewing data-collection efforts and methods described in the 1985 report, "Estimated use of water in the United States," in preparation for the 1990 update. 


\section{New York Water-Use Data \\ (NY 79-007 continued)}

Completed reports (since 1985):

Snavely, D.S., 1986, Water-use data-collection programs and regional data base of the Great Lakes-St. Lawrence River basin States and Provinces: U.S. Geological Survey Open-File Report 86-546, 204 p.

1988, Estimation, analysis, sources, and verification of consumptive water use in the Great Lakes-St. Lawrence River basin: U.S.Geological Survey Water- Resources Investigations Report 88-4146, 28 p.

1988, Great Lakes water-use data-baseplanning for the twenty-first century; in United States Geological Survey Fiscal Yearbook 1987: Washington, D. C., p. 9398.
1988, Great Lakes Regional Water-Use Data Base--a water resources management tool, in Waterstone, M., and Burt, R. J., eds., Water-use data for water-resources management: American Water Resources Association, Proceedings, August 1988, p. 397-406

1989, Water use in New York, 1985:

U. S. Geological Survey Open-File Report 88-727, Water Fact Sheet, 2 p.

Snavely, D. S., and Williams, James, 1985, Estimated public-water supply and industrial-commercial ground-water withdrawals and return in Nassau County, Long Island, New York, 1973-79: U.S. Geological Survey Water-Resources Investigations Report 84-4246, 204 p. 
Period of project: Continuous since July 1966

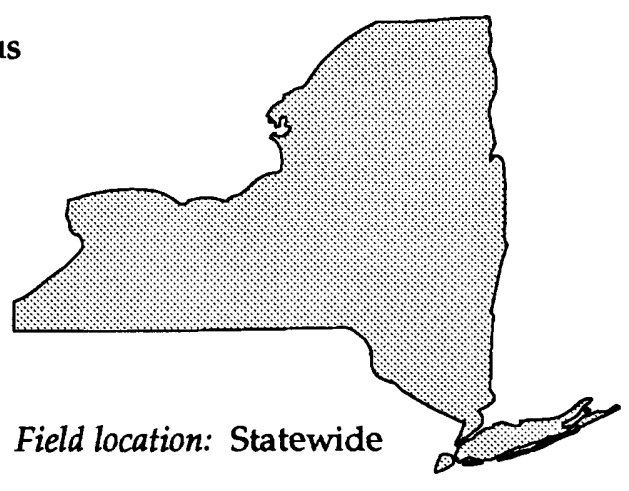

Project leader: Richard Lumia
Cooperating agency: New York State Department of Transportation

Problem: Flooding is a serious problem in many parts of the State. Information on floods and analyses of flood data are needed to aid in the design of bridges, highways, and buildings, and in flood-plain zoning and flood-protection works.

Objective: (1) To provide information on magnitude and frequency of floods to agencies and individuals involved in flood-protection planning and design. (2) To develop regional flood-frequency relationships for the entire State. (3) To make site studies.

Approach: To (a) collect flood data at creststage stations and publish annual peak discharges; (b) calculate discharges of floods, develop flood profiles, and collect information for flood-plain mapping; (c) prepare reports covering individual floods, and (d) make analyses to improve flood-frequency relationships for the State.

Progress and significant results: Regional floodfrequency relationships for New York State were developed, and a report is in preparation. Data collection continued at creststage stations and annual peaks were published in the annual water data report. A report on the April 1987 flood in southeastern
New York was published.

Plans for next year: (1) To complete a report on flood-frequency relationships for New York streams. (2) To continue data collection at crest-stage stations. (3) To document any notable floods. (4) To begin an analysis for updating the maximum known stages and discharges of New York streams.

Completed reports (since 1984):

Lumia, Richard, Burke, P. M., and Johnston. W. H., 1986, Flooding of December 29, 1984 through January 2, 1985 in northern New York State with flood profiles of the Black and Salmon Rivers: U. S. Geological Survey Water-Resources Investigations Report 86-4292, 53 p.

Lumia, Richard and Johnston, W. H., 1984, Floods of August 7-8, 1979, in Chautauqua County, New York, with hydraulic analy-sis of Canadaway Creek in the Village of Fredonia: U.S. Geological Survey Water-Resources Investigations Report 83-4211, 16 p.

Robideau, J. A., Burke, P. M. and Lumia, Richard, 1984, Maximum known stages and discharges of New York streams through September 1983: U.S. Geological Survey Open-File Report 83-927, 83 p. 
Period of project: Continuous since February 1977
Cooperating agency: New York State Department of Environmental Conservation

Problem: The industrial discharge of PCBs (polychlorinated biphenyls) into the upper Hudson River has degraded the water quality. The effectiveness of proposed sedimentdredging operations in the upper Hudson remains unknown until it is determined whether or not significant quantities of PCB-contaminated sediment have been transported downstream.

Objective: To estimate the amount of PCBs contributed from the upper Hudson River to the estuary and determine whether PCBcontaminated sediments have been transported into the estuary. This study will provide a data base from which the effects of dredging the upper Hudson (if carried out) can be evaluated.

Approach: Annual PCB and sediment loads for the Hudson River will be calculated from daily flow and sediment data.

Progress and significant results: Annual suspended sediment loads and PCB loads were calculated for water year 1988. Loads were compared to those of preceding years.
Samples of two high flows were collected in water year 1989 and delivered to laboratories for analysis. Much of the sampled flow came from above Fort Edward and passed over "hot spots" (areas of high PCB concentrations) in bottom sediments.

Plans for next year: To update reporting on PCB transport.

Completed reports (since 1981):

Schroeder, R. A. and Barnes, C. R., 1983, Polychlorinated biphenyl concentrations in Hudson River water and treated drinking water at Waterford, New York: U.S. Geological Survey Water-Resources Investigations Report 83-4188, 13 p.

1983, Trends in polychlorinated biphenyl concentrations in Hudson River water 5 years after elimination of point sources in 1976: U.S. Geological Survey Water-Resources Investigations Report 83-4206, 28 p.

Sloan, R. J., Simpson, K. W., Schroeder, R. A. and Barnes, C. R., 1983, Temporal trends toward stability of Hudson River PCB contamination: Bulletin of Environmental 


\section{Transport of Polychlorinated Biphenyl (PCB) Residues \\ in the Upper Hudson River Basin \\ (NY 77-046 continued)}

Contamination and Toxicology, v. 31, p. 377-385.

Sloan, R. J., Brown, M. P., Brandt, R. J. and Barnes, C. R., 1984, Hudson River PCB relationships between resident fish, water, and sediments: Northeastern Environmental Science, v. 3, p. 138-152.

Turk, J. T., 1980, Applications of Hudson River basin PCB transport studies, in Baker, $R$. L., ed., Contaminants and sediments: Ann Arbor Science Publishers, v. 1, p.
171-183.

Turk, J. T. and Troutman, D. E., 1981, Relationship of water sources to water quality in the Hudson River, New York, during peak discharges to geologic characteristics of contributing subbasins: U.S. Geological Survey Water- Resources Investigations Report 80-108, 15 p.

1981, Polychlorinated biphenyl transport in the Hudson River, New York: U.S. Geological Survey Water-Resources Investigations Report 81-9, 11 p. 


\section{Baseline Water Quality Assessment of Selected Aquifers \\ (NY 82-114)}

Period of project: Continuous since October 1981

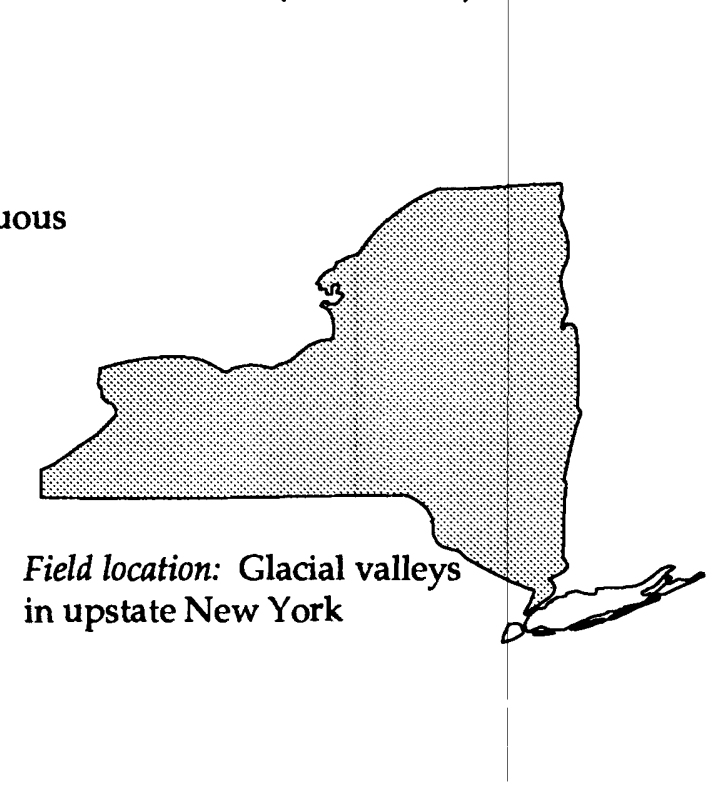

Project leader:

Richard J. Reynolds
Cooperating agency: New York State Department of Environmental Conservation

Problem: Most principal aquifers in upstate New York are isolated unconfined glacial or alluvial deposits in valleys cut into crystalline or shale bedrock. Development has rendered these aquifers susceptible to contamination. Contamination, whether from agricultural, industrial, or nonpoint sources, jeopardizes the only economical source of water for homes, communities, and small industries in many places. Management's decision to resolve or prevent this problem would be facilitated by an appraisal of selected areas of known or potential contamination.

Objectives: (1) To select aquifers that have known or potential ground-water contamination (such as Utica-Rome area or Clifton Park). (2) To compile geohydrologic maps of the aquifer systems. (3) To select a ground-waterquality monitoring system for major watersupply users. (4) To sample and analyze ground water for baseline quality.

Approach: Aquifer selection will be flexible, depending on the needs of the cooperating agency. Aquifers will be mapped generally at the 1:24,000 scale from published geologic, soils, and land-use maps or minor field mapping. Aquifer characteristics will be interpreted and depicted on aquifer-thickness, water-level, and water-quality maps and geologic sections.

Progress and significant results: Three reports covering the Utica and Rome areas were published, along with a report on the CrotonOssining area and one on the Hornell area. The Owego report is in press. Reports covering the Norwich-Oxford-Brisben area and the Sand Ridge aquifer in Oswego County are in review. Work on the Schodack Terrace aquifer in Rensselaer and Columbia Counties, as well as a reinvestigation into the Clifton Park area, are underway.

Plans for next year: (1) To publish the reports on the Norwich-Oxford-Brisben area, the Sand Ridge aquifer, and the Schodack Terrace aquifer. (2) To complete a report on the Waverly-Sayre area. (3) To collect additional hydrogeologic and water-quality data from the Clifton Park area. (4) To establish several observation wells in the Colonie Channel aquifer and to monitor water records with continuous recorders. (5) To prepare a potentiometric-surface map of the Colonie Channel aquifer if data are sufficient. 


\section{Baseline Water Quality Assessment of Selected Aquifers \\ (NY 82-114 continued)}

Completed reports (since 1984):

Casey, G. D. and Reynolds, R. J., 1989, Hydrogeology of the stratified-drift aquifer in the Rome area, Oneida County, New York: U.S. Geological Survey WaterResources Investigations Report 88-4155, 8 sheets, scale 1:24,000.

1989, Hydrogeology of the stratifieddrift aquifer in the Utica area, Oneida County, New York, part 1 (west): U.S. Geological Survey Water-Resources Investigations Report 88-4194, 8 sheets, scale $1: 24,000$.

1989, Hydrogeology of the stratifieddrift aquifer in the Utica area, Oneida and Herkimer Counties, New York, part 2 (east): U.S. Geological Survey WaterResources Investigations Report 88-4195, 8 sheets, scale 1:24,000.

Miller, T. S., Warren, C. C., and McPherson, W.S., 1990, Geohydroogy of the surficial aquifer in the Hornell area, Steuben and Allegany Counties, New York: U.S. Geological Survey Water-Resources Investigations Report 89-4053, 7 sheets, scale $1: 24,000$.

Reynolds, R. J., 1984, Hydrogeology of the Clifton Park area, Saratoga County, New York: U.S. Geological Survey Water-
Resources Investigation Report 84-4031, 6 sheets, scale 1:24,000.

1986, Hydrogeology of the Fort Drum area, Jefferson, Lewis and St. Lawrence Counties, New York: U. S. Geological Survey Water-Resources Investigations Report 85-4119, 6 sheets, scale 1:48,000.

1988, Availability of ground-water from unconsolidated deposits in the Mohawk River basin in southern Herkimer County, New York: Herkimer-Oneida Counties Water Resources Planning Report No. 1, 3 sheets, scale 1:95,040.

1988, Hydrogeology of the CrotonOssining area, Westchester County, New York: U.S. Geological Survey WaterResources Investigations Report 87-4159, 5 sheets, scale 1:12,000.

Zarriello, P. J., 1986, Hydrogeology of the Salamanca area, Cattaraugus County, New York: U.S. Geological Survey Water-Resources Investigations Report 85- 4149, 5 sheets, scale 1:24,000.

Zarriello, P. J. and Reynolds, R. J., 1986, Hydrogeology of the Olean area, Cattaraugus County, New York: U.S. Geological Survey Water-Resources Investigations Report 85-4157, 9 sheets, scale 1:24,000. 


\section{Response of Fish and Invertebrates to Episodic Changes in Stream Chemistry and Discharge at Four Streams, and Long-Term Monitoring of Seven Streams in the Catskill Mountains \\ (NY 85-152)}

Period of project: October 1984 through October 1990

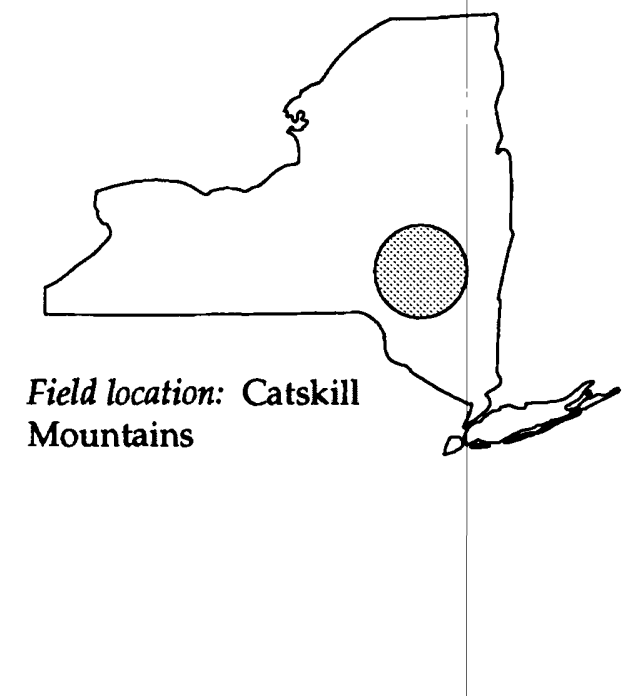

Project leader: Peter S. Murdoch
Cooperating agency: United States Environmental Protection Agency

Problem: Reconnaissance data suggest that acid precipitation may affect stream chemistry in the Catskill Mountains. Assessment of the processes that cause stream acidification and the effect of acid deposition on fish and invertebrates requires data on both short-term and long-term trends in stream chemistry.

Objective: (1) To asses the relations among soil chemistry, stream chemistry, and discharge at four streams of differing base-flow pH. (2) To calculate a mass balance for input and output of key constituents through the respective watershed. (3) To compare the effect of precipitation acidity of selected storms on the geochemistry of these streams. (4) To assess the effect of episodic acidification on fish and invertebrate populations. (5) To assess the long-term changes in stream chemistry at seven Catskill streams.

Approach: To conduct (a) hourly sampling of stream and rainwater during 10 storms at the four streams, (b) weekly sampling during nonstorm periods, (c) weekly sampling of wetfall within the Biscuit Brook watershed as part of the NTN (National Trends Network) program, (d) monthly sampling at seven streams peripheral to the Biscuit Brook watershed with simultaneous discharge measurements, and (e) monitoring of biologic response by population estimates, bioassay experiments, and radiotelemetry studies.

Progress and significant results: Long-term monitoring continued. Relations between constituents and flow were developed for all streams in the network. Storm data show increased nitrate concentrations associated with flow increases, except during midsummer. Populations of fish and invertebrates are smaller in the acidic streams than in the more buffered streams. Fish held in streams during acid episodes showed a significantly increased mortality rate.

Plans for next year: To complete long-term monitoring and the episodic response project.

Completed reports:

Murdoch, P. S., and Barnes, C. R., 1987, Assessment of stream acidification in the Catskill Mountains of New York, in Programs and Abstracts: American Chemical Society, 17th Northeast Regional Meeting, Rochester, N.Y., November 8-11, 1987, p. 84. 


\section{Sorptive and Transport Characteristics of PCB Congeners in the Upper Hudson River \\ (NY 86-165)}

Period of project: July 1986 through September 1990

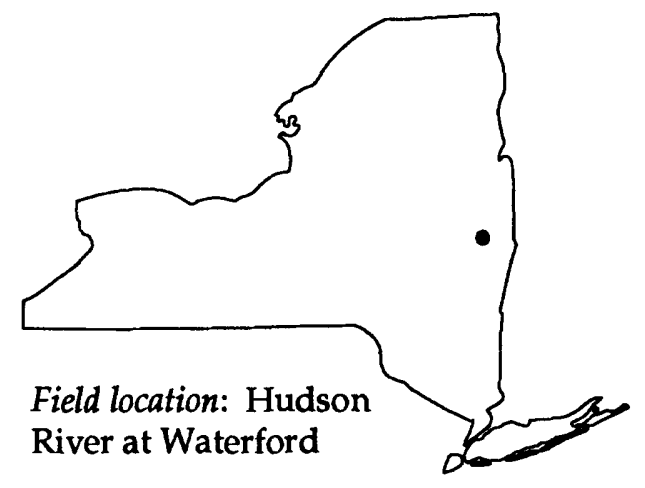

Project leader: Robert F. Snow

Cooperating agency: New York State Department of Environmental Conservation

Problem: PCBs (polychlorinated biphenyls) are mixtures of up to 209 individual congeners, each having different physical characteristics and environmental hazards. To further our understanding of transport mechanisms, information is needed to determine which PCB congeners are present during selected flow regimes.

Objectives: (1) To examine the PCB congener distribution in water and suspended sediment during a variety of flow conditions. (2) To examine partitioning of $\mathrm{PCB}$ congeners transported in dissolved and suspended phases. (3) To compare theoretical desorptive processes in riverbed and suspended material with concentrations of PCBs during the transition period following high flows. (4) To examine the relation between high-flow and low-flow concentrations of PCB congeners to see if high-flow data can be used to estimate congener distribution later in the year. (5) To compare congener analyses with results of generic aroclor analyses.

Approach: Samples will be collected from the last high flow of the spring that exceeds 708 cubic meters per second.. The samples will be from the rising limb, peak, and falling limb of the flood. Aliquots of selected samples will be analyzed in the Survey's National WaterQuality Laboratory in Denver and in the New York State Department of Environmental Conservation's laboratory in Albany. The relations of congeneric composition of dissolved and suspended PCBs to discharge will be examined.

Progress and significant results: Samples of two high flows were collected in the spring of 1989 and delivered to the State laboratory for congener analysis and to the Survey's National Water-Quality Laboratory for aroclor analyses.

Plans for next year: To prepare the final report. 


\section{Westchester Ground-Water Study \\ (NY 87-167)}

Period of project: July 1985 through June 1989

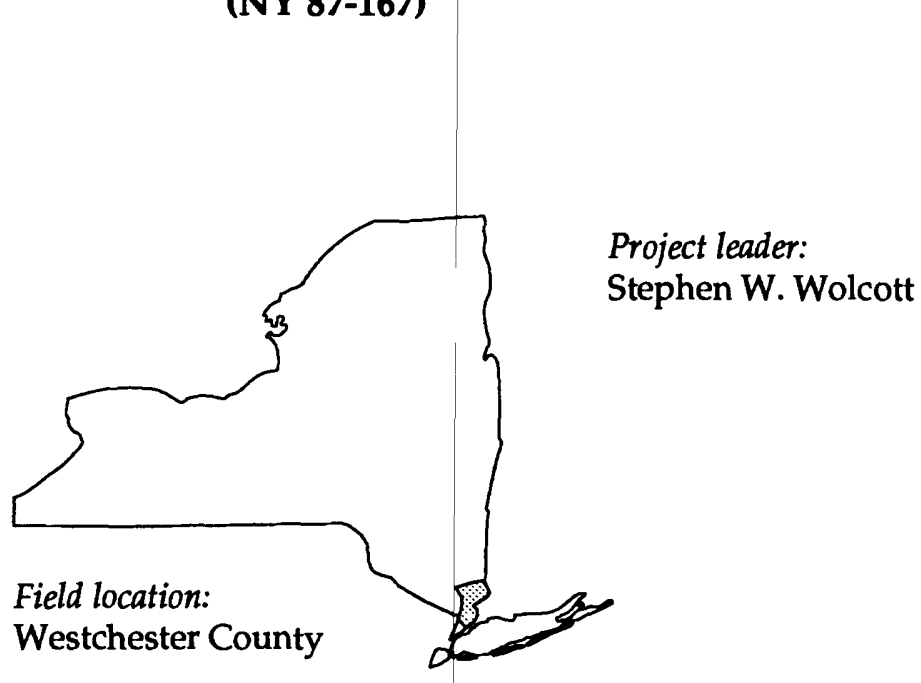

Cooperating Agency: Westchester County Water Agency

Problem: The limits of growth and development within the upper Croton River basin in Westchester County remain unclear because the availability and quality of ground water are unknown. Ground water derived from bedrock is of concern because most of the unconsolidated aquifers have been developed to their maximum potential, do not supply sufficient quantities of water, or have been contaminated. Withdrawals of water from bedrock aquifers must not exceed the annual recharge rate to prevent depletion.

Objectives: To estimate the natural recharge rate and define the baseline water quality of till and bedrock aquifer systems.

Approach: (1) To estimate the rate of recharge to till and bedrock aquifers through an estimating technique for analyzing the ground-water component of mean annual runoff. (2) To calibrate a steady-state groundwater model of a selected subbasin within the study area to verify the estimates and investi- gate the hydrogeologic flow processes in upland areas. (3) To collect water samples from each major bedrock unit for chemical analysis.

Progress and significant results: Ground-water modeling has been completed, and two reports are near completion. One summarizes the recharge rates and chemical quality of water from bedrock aquifers; the other is a map with text showing estimated thickness and well yields of stratified-drift deposits in selected areas of northern Westchester County.

Plans for next year: To complete the final reports.

\section{Completed reports:}

Wolcott, S. W. and Irwin, D. J., 1988, Estimated thickness and potential well yield of stratified-drift deposits in the upper Croton River basin, Westchester County, New York: U. S. Geological Survey Water-Resources Investigations Report $87-4287,6$ plates, scale $1: 24,000$. 


\section{Glacial Aquifers of the Northern Hudson-Mohawk Lowlands in Saratoga County: Data-Base Development and Surficial Geology \\ (NY 88-171)}

Period of project: April 1988 through April 1990

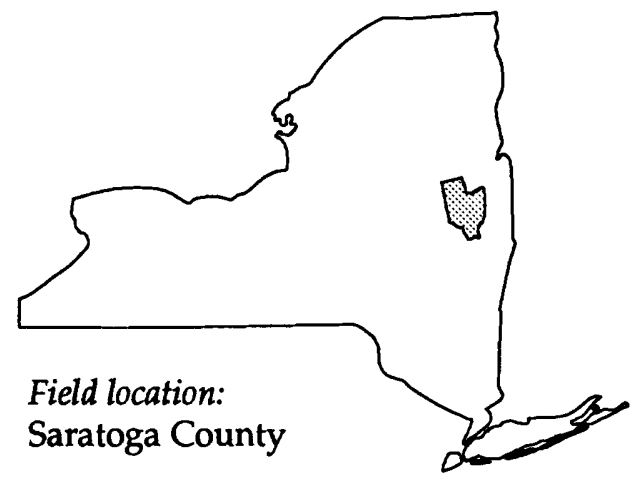

Project leader: Paul Heisig

Cooperating agency: Saratoga County Environmental Management Council

Problem: The water resources associated with unconsolidated deposits of the HudsonMohawk Lowlands of Saratoga County are stressed by population growth and are vulnerable to contamination from various sources. To define potential and currently used aquifers is an integral step in water-supply management and protection of ground-water resources.

Objective: (1) To develop a data base of spatially related information. (2) To identify currently used and potential aquifers in the unconsolidated deposits of the study area.

Approach: (1) Compile and digitize available information. (2) Conduct a well inventory. (3) Establish a GIS (Geographic Information System) data base for well locations. (4) Obtain surficial geology and pumpage data.

Progress and significant results: The well locations have been digitized and entered into USGS and GIS data bases. Surficial geology maps have been obtained.

Plans for next year: To compile and prepare well and pumpage data; compile surficial geology, well locations and pumpage data on quadrangle maps; and prepare map text. 


\section{Hydrologic Budget and Changes in Aquatic Chemistry of Woods Lake Outlet after Watershed Liming \\ (NY 88-173)}

Period of project: October 1988 through September 1991

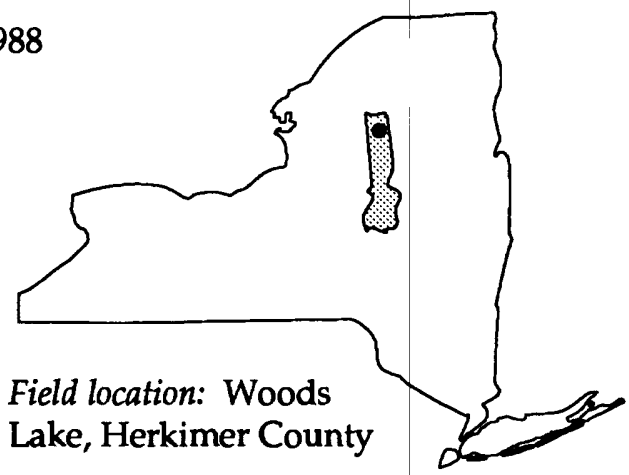

Project leader: Douglas A. Burns

Cooperating agency: Cornell University, Department of Natural Resources

Problem: To determine the magnitude of chemical changes, including acidification mitigation, in a lake-outlet stream after lakewatershed liming.

Objective: (1) To determine the effects of watershed liming on the lake-outlet stream. (2) To identify the processes that alter or control stream-water chemistry. (3) To determine how the effects of watershed liming change through time.

Approach: Determine longitudinal chemical changes and mass balances for the outlet stream through water sampling and operation of continuous stream gages.

Progress and significant results: Base-flow samples have been collected and analyzed. Longitudinal sampling profiles were completed in May, August, and September 1989. Several high-flow samples were collected during snowmelt runoff.

Plans for next year: To (a) sample the lake outlet daily after the watershed liming, (b) repeat longitudinal sampling during spring, fall, and summer, (c) document the duration and magnitude of liming effects on the outlet stream, and (d) identify the processes that control chemical changes along the outlet stream. 


\section{Resource Management Evaluation and Study of Saltwater Movement Within the Transition Zone of the Hudson River Estuary (NY 88-175)}

Period of project: May 1988 through September 1992

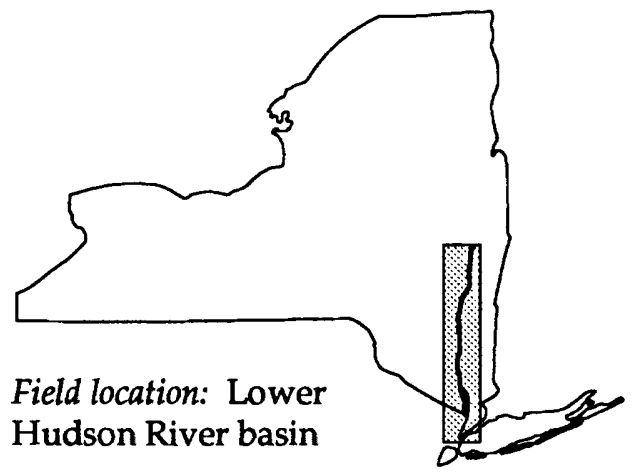

Project leader: Ward O. Freeman
Cooperating agencies: City of New York; New York State Department of Environmental Conservation

Problem: The effect of major freshwater withdrawals on salinity in the transition zone of the Hudson River is unknown. Increased salinity and upstream movement of the salt front could adversely affect habitats in the river and water supplies. As a result, new water supplies cannot be developed until their probable effect on saltwater movement can be determined.

Objective: (1) To identify and describe the forces that determine the location and shape of the salt front. (2) To identify the effect of seasonal variations and channel geometry on the location of the salt front. (3) To predict the effect of water withdrawals at different points on the location of the salt front.

Approach: This study will be divided into several phases that include: (a) identifying and evaluating present models, data, and data-collection programs for the Hudson River estuary; (b) installing tide-stage and waterquality stations at several locations; (c) developing and using a one-dimensional model to evaluate what additional data and datacollection sites are needed: (d) performing several tidal-cycle discharge and salinity measurements under differing hydrologic conditions; (e) using these data to calibrate and verify one- and two-dimensional models to simulate the forces that control flow and saltwater movement in the estuary; and ( $f$ ) evaluating several water-withdrawal plans with these models.

Progress and significant results: The data-collection program has three main aspects. The first is the long-term continuous-record program that includes six continuous-record water-quality and tide-stage gages, chlorideconcentration data, and two weather stations . The continuous record helps to describe the seasonal effects on the movement of the salt front and provides boundary conditions for the digital models. The second aspect of the data-collection program is the salt-front delineation studies. Six of these studies were performed in 1989 to identify the longitudinal variation of chloride concentration during high-slack (slack-before-ebb) tide conditions. The salt front, defined as 100 milligrams per liter of chloride, ranged from Ossining to New Hamburg throughout the year. The 


\section{Albany office}

\section{Resource Management Evaluation and Study of Saltwater Movement Within the Transition Zone of the Hudson River Estuary (NY 88-175 continued)}

third aspect of the data-collection program is the tidal-cycle discharge and chloride-concentration profiles. Four of these 20 -hour, intensive data-collection efforts were performed, each with more than 100 discharge measurements in the cross section and detailed horizontal and vertical velocity measurements and specific conductance data. Results show discharge rates as high as $200,000 \mathrm{ft}^{3} / \mathrm{s}$ (cubic feet per second) and as low as $15 \mathrm{ft}^{3} / \mathrm{s}$. Chloride concentrations indicate that the transition zone of the estuary is partially mixed in some areas and behaves as a salt wedge in others.
All of these data are in the project data base, and most are to be included in the national water information system.

Plans for next year: Six additional salt-front data collections will be performed during five intensive tidal-cycle efforts. These data will be used to calibrate and verify a one-dimensional flow and solute transport model and to begin work with multidimensional models. A GIS data base, including digital elevation data and bathymetry data, will be developed and interfaced with the models. 


\section{Evaluation of Scour at Bridges in New York \\ (NY 88-178)}

Period of project: July 1988 through September 1993

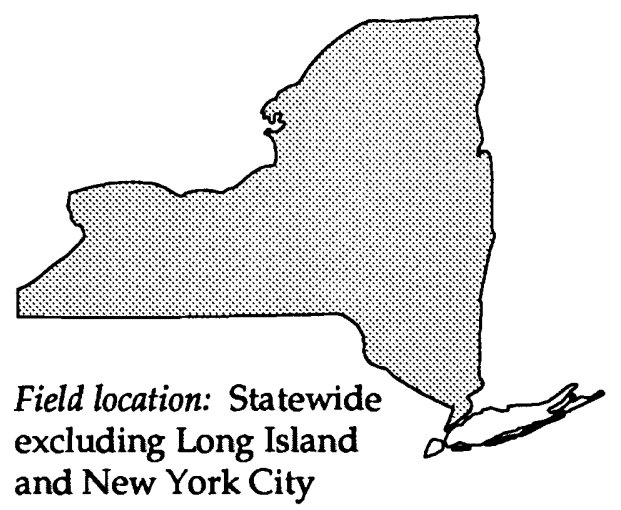

Project leader: Gerard K. Butch
Cooperating agency: New York State Department of Transportation

Problem: No reliable technique is available to estimate scour at bridges in New York. Uncertainty as to which scour-prediction equations to use for a particular set of circumstances has prompted an effort to develop data bases that reflect full-scale, prototype field conditions. The types of channels and bridges that are vulnerable to scour, and reliable data-collection methods, need to be identified.

Objective: (1) To collect scour data to evaluate and perhaps improve current scour-prediction equations. (2) To categorize the types of channels and bridge designs vulnerable to scour.

(3) To assess alternative methods of data collection.

Approach: Bridge sites will be selected for scour-data collection, including 35 sites for measurement during high flows. Sites not selected for flood measurements will be inspected annually. Measurement techniques will include equipment and procedures used by the U.S. Geological Survey along with geophysical techniques. The type(s) and extent of scour will be examined. Results of scourprediction equations will be compared with measured scour. Regression analyses and (or) other curve-fitting techniques will be used to improve scour-prediction equations. The types of channels and bridges vulnerable to scour will be categorized.

Progress and significant results: Seventy-six sites were selected for scour-data collection, including 31 flood-data sites and 45 annualdata sites. Base-line cross sections and elevation controls were established at all sites. Inspection reports and bridge plans were obtained from the New York State Department of Transportation. Flood-frequency analysis was performed at flood-data sites. Scour data were collected at nine sites during mean annual flows. Conventional and alternative measurement techniques were applied.

Plans for next year: To continue data collection at all sites with conventional and alternative methods and to write the final report. 


\section{Water Flow Paths in Two Limed Inlet Watersheds at Woods Lake}

(NY 89-181)

Period of project: May 1989 through September 1991

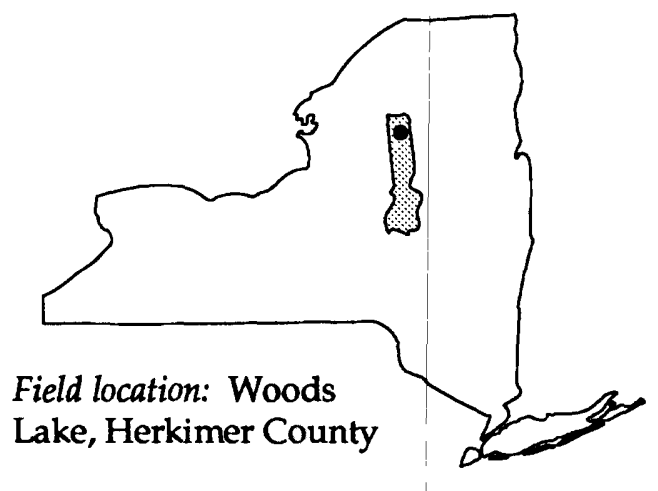

Project leader: Douglas A. Burns

Cooperating agency: Cornell University, Department of Natural Resources

Problem: Watershed liming is being investigated as a possible method of mitigating the effects of acidic precipitation on lake-water chemistry and biota. The hydrologic flow paths of incoming precipitation and melting snow are important in controlling the acidity of lake tributaries and the lake itself. Hydrologic flow paths are expected to prove important in controlling the neutralization process after lime addition.

Objective: (1) To quantify the relative amounts of precipitation, soil water, and ground water entering two Woods Lake inlet streams during periods of high flow. (2) To determine the implications of the hydrologic flow paths on the magnitude and expected duration of buffering effects in the inlet streams and lake.
Approach: (1) Collect monthly background samples of precipitation, soil water, ground water, and stream water to examine the variability of isotopic ratios. (2) Determine the isotopic ratios of streamwater and precipitation during at least three high-flow periods each year. (3) Use additional flow-path-separation techniques to verify the results obtained from isotope analysis.

Progress and significant results: Background samples of precipitation, stream water and ground water were collected during the summer of 1989. One high flow in one of the inlet streams was sampled in late September.

Plans for next year: To sample at least three high flows in each inlet stream. Background sample collection will continue throughout the year. 


\section{Channel-Roughness Characteristics ("n" Value) Verification \\ (NY 84-140)}

Period of project: October 1983 through September 1990

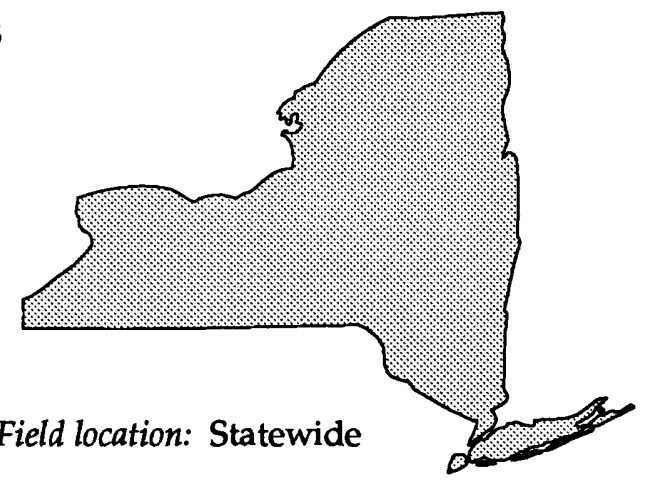

Project leader: William F. Coon
Cooperating agency: New York State Department of Transportation

Problem: Indirect computation of flood discharges and flood profiles requires estimates of channel-roughness coefficients (" $n$ " values). The reliability of slope-area (indirect) measurements of discharge and step backwater analyses is heavily dependent on the evaluation of channel roughness. Although several guides for estimating " $n$ " values for natural channels are available, subjective judgment will probably always play a part in the final determination when all factors (streambed constituency, bank and flood-plain vegetation, channel shape and curvature, depth of water, etc.) are considered.

Objective: (1) To develop site-specific relations between " $n$ " values and such variables as flood depth and seasonal variation of vegetation cover. (2) To assess the transferability of these relations to other sites. (3) To compile and maintain a file for each site that includes site maps, cross-section plots, site plans, photographs, and stereo slides that can be duplicated and used for office and field-training exercises.

Approach: Select 30 to 40 sites at well-rated gaging stations. After a flood, make a slopearea measurement to obtain the initial " $n$ " verification and cross-section location for subsequent installation of crest-stage gages.
Operate crest-stage gages until enough record is collected to define the roughness characteristics of the reach and the relation between roughness and variables such as depth and vegetation. Evaluate the transferability of sitespecific relations based on the data from the 30 to 40 sites.

Progress and significant results: Bed-material data and streambank-vegetation descriptions were collected at the 24 sites retained in the study. A thorough review of hydraulic data, including crest-stage gage elevations, watersurface elevations, discharges, cross-section geometry, and reach lengths, was conducted. Large discrepancies in computed " $n$ " values between subreaches for a given discharge were found at several sites. These discrepancies are assumed to be the result of exceeding the hydraulic limitations of the Manning formula because of indeterminant energy losses resulting from expanding flow in the study reach, large variation in channel crosssection, non-effective flow area, and negative bed slope.

Plans for next year: To continue the statistical data analysis to determine the validity of developing an $n$-value predictive equation to assess the study results in light of currently available predictive equations, and determine the transferrability of these results to nonstudy sites and to complete the final report. 


\section{Effects of an Instream Impoundment on Runoff and Water Quality in a Small Residential Headwater Basin (NY 86-161)}

Period of project: January 1986 through September 1990

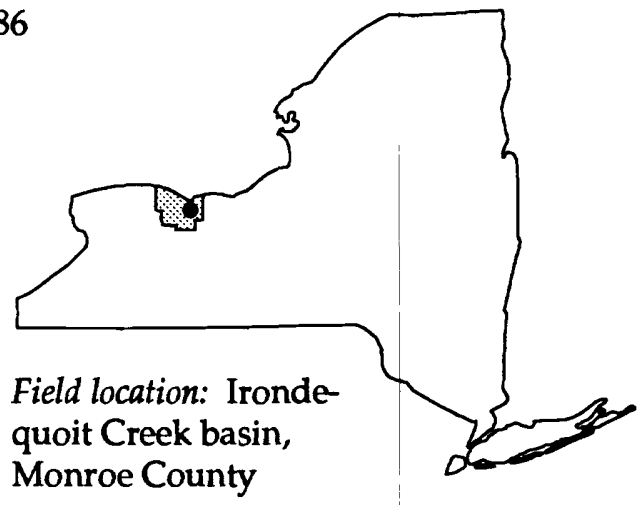

Project leader: Phillip J. Zarriello

Cooperating agency: Monroe County Environmental Health Laboratory

Problem: The use of flow-detention basins to improve the chemical quality of stormflow was recommended by the U.S Environmental Protection Agency's National Urban Runoff Program on the basis of a limited amount of data. A more detailed analysis of the effect of detention basins on runoff quality is needed to assess the performance of detention basins and to help local water managers determine the cost effectiveness of using such structures to improve the quality of downstream receiving waters.

Objectives: To evaluate the effects of a detention basin on stormwater quality by retaining constituent loads.

Approach: The inflow to and outflow from a detention basin will be monitored for flow and water quality for 3 years. Precipitation data will be collected within the watershed to establish rainfall-to-runoff relationships. Basin characteristics will be documented. Data will be analyzed to determine changes in constituent concentration and mass flux through the detention basin. The outflow to the detention basin will be modified in subsequent years to increase retention time to enhance constituent removal. Trap efficiencies will be determined for selected constitu- ents for each of three control configurations. Significant differences between inflow and outflow loads and different control configurations will be determined by statistical test. Inflow will be compared with outflow to assess hydrologic and water-quality differences.

Progress and significant results: Stormflow data and water-quality samples were collected during major storms from August 1986 through September 1989. Loads of 20 constituents representing nutrients, metals, physically related chemical properties and common ions were calculated for the inflow and outflow of the detention basin. Trap efficiencies were calculated for individual storms, summary of storm loads, and regression methods. Efficiency varied among constituents that have a greater proportion of their load in suspension (phosphorus, lead, and zinc), and these showed greater retention than constituents that are less highly affiliated with suspended matter. Retention improved for most constituents as the control was modified to increase retention time. Changing hydrologic conditions from year to year complicated the comparisons between control configurations. The second year of the study represented a record drought year, as reflected by low constituent loads.

Plans for next year: To publish the final report. 


\section{Hydrogeology of the Niagara Falls Area \\ (NY 86-164)}

Period of project: June 1986 through September 1991

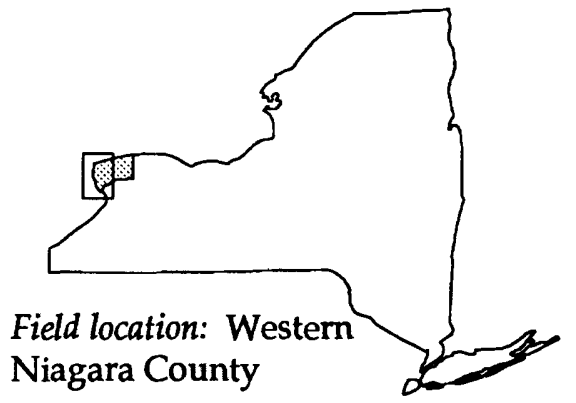

Project leader: William M. Kappel

\section{Cooperating agency: U.S. Environmental Protection Agency}

Problem: Ground-water and surface-water quality along the Niagara River have been degraded by direct discharge and migration of contaminants from industrial plants and waste-burial sites for more than 50 years. The Niagara Falls area alone contains nine Superfund sites and more than 30 waste-burial sites. A regional ground-water-flow study is needed to evaluate the effect of these sites on the surface-water and ground-water resources of the Niagara Falls area in both the United States and Canada.

Objectives: (1) To define the hydrogeologic characteristics of surficial and bedrock units in the area. (2) To describe the natural chemical quality of ground water in the bedrock aquifers. (3) To develop a three-dimensional flow model to describe hydrologic conditions and ground-water flow patterns and provide a basis for initial boundary conditions for future site-specific modeling.

Approach: This study has four phases. Phase 1 is the compilation of available hydrogeologic and water-quality information, and developing a conceptual ground-water model; phase 2 entails field investigations and initial development and calibration of a three-dimensional ground-water model and geochemical model; phase 3 involves calibration and sensitivity analyses of the three-dimensional model; and phase 4 entails the final data analysis.

Progress and significant results: Regional waterbearing zones were defined for the entire
Lockport Group and the Vernon/ShaleLockport/Dolomite contact. Simulation of drawdowns with two-dimensional models representing pumped (water-bearing) zones at the cross-hole testing site (NI-1) was completed. Estimates of transmissivity range from $1 \times 10^{-4}$ to $6 \times 10^{-4} \mathrm{~m}^{2} / \mathrm{s}$ (meters squared per second) if a uniform transmissivity within each pumped zone is assumed; discretizing the pumped layer into zones bounded by vertical fractures (interpreted from previous surface geophysical surveys) gives transmissivity values of $2 \times 10^{-1}$ to $3 \times 10^{-7} \mathrm{~m}^{2} / \mathrm{s}$. Storativity values ranged from $10^{-4}$ to $10^{-5}$. Vertical hydraulic conductivity was $6 \times 10^{-7}$ meters per second under the assumption of homogeneity; simulations that assume heterogeneity are underway. Analyses of shallow bedrock water-level fluctuations in relation to the Niagara River, Forebay Canal and exterior conduit drains, and the pumped-storage reservoir fluctuations were completed.

Plans for next year: The regional three-dimensional model and the final report will be completed.

\section{Completed reports:}

Yager, R M. and Kappel, W. M., 1987, Detection and characterization of fractures and their relation to groundwater movement in the Lockport Dolomite, Niagara County, New York, in Pollution, Risk Assessment and Remediation in Groundwater Systems: Khanbilvardi, R. M., and Filos, J., eds., Washington, D. C., Scientific Publications Co., p. 149-1 


\section{Subsurface Transport of Pesticides and Nitrates in Fields under Conventional and Conservation Tillage Practices \\ (NY 87-169)}

Period of project: January 1987 through September 1989

\section{7}

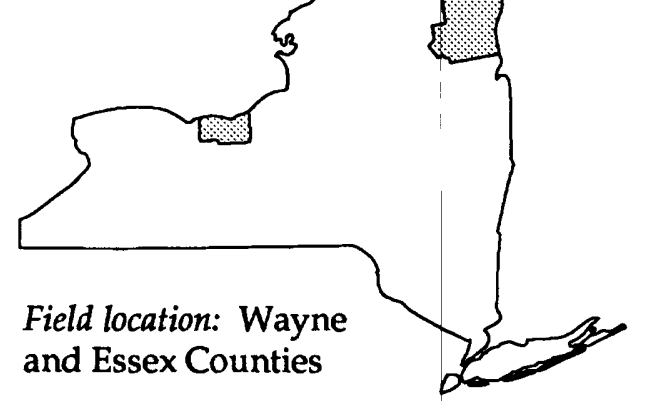

Project leader: Jan Surface

\section{Cooperating agency: Cornell University}

Problem: Agricultural chemicals such as nitrates and pesticides have been identified as a source of ground-water contamination nationally as well as in New York State. Water in soil often does not flow in a uniform, easily predictable manner, but instead, as a result of macropores or unstable wetting fronts, it may flow along preferential paths and reach deep into the subsoil more quickly than expected. Conservation tillage (no-till) is being promoted in New York State because it decreases erosion. No-till changes the soil's hydraulic characteristics and may lead to a potential increase in the rate of nitrate and pesticide migration to the ground water.

Objectives: To study the downward movement of water, nitrates, and pesticides in fields under conventional and no-till practices and determine whether solute migration in either practice poses a significant threat to groundwater quality.

Approach: Field data will be collected to study the soil-hydrology changes that result from the conversion to no-till practices. Paired fields will be managed under conventional tillage and no-till practices, and solute movement will be studied. Site selection, instrumentation, installation and collection of background data will be completed in the first year. Pesticide, nitrate, and solute-tracer transport will be monitored the following year.

Progress and significant results: The no-till field showed low concentrations of atrazine and alachor below the root zone about 1 month after the application, but the conventionally tilled plot showed no pesticides below the root zone. Dye studies indicated that some of the pesticide in the no-till plots bypassed the root zone through surface-connected macropores, while most of the pesticide in the conventionally tilled plot was absorbed within the root zone as a result of greater soil contact. Nitrate was found only in that part of the profile that remained unsaturated throughout the experiment. A journal article was written and colleague reviews completed.

Plans for next year: To publish the final report.

Completed reports:

Steenhuis, T. S., Staubitz, W., Andreini, M. S., Surface, Jan, Richard, T. L., Paulsen, Robert, Pickering, N. B., Hagerman, J. R., and Geohring, L. D., 1990, Preferential movement of pesticides and tracers in agricultural soils: Journal of Irrigation and Drainage Engineering, v. 116, no. 1, p. 5066. 


\section{Fate and Transport of Landfill Leachate in a Phragmites Wetland \\ (NY 88-170)}

Period of project: October 1987 through October 1991

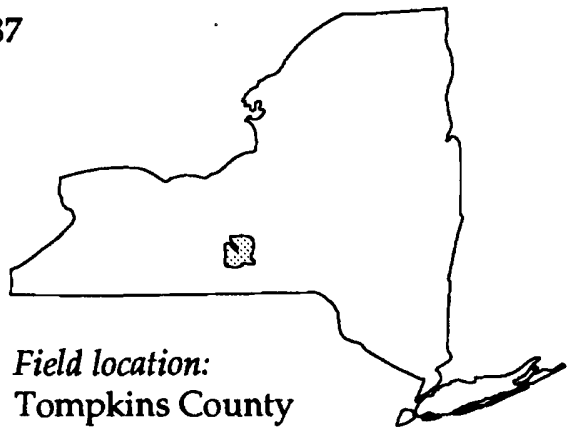

will be determined, water and chemical mass loadings will be calculated, and treatment efficiencies of each plot will be evaluated.

Progress and significant results: The leachate beds were constructed, and the Phragmites were planted. The leachate-holding tank, delivery line and metering equipment, and piping for delivering the leachate to the beds were installed. Sampling of leachate began in 1990 , and the laboratory analysis has been contracted with Cornell University, the U.S. Geological Survey laboratory in Trenton, N. J. and the Adirondack Environmental Laboratory. A paper on the potential use of wetlands to treat landfill leachate was presented in June 1988 and November 1989.

Plans for next year: Leachate application should continue throughout the year. Sampling should begin shortly thereafter and will include an analysis of selected constituents on a regular basis. A full scan of priority pollutants at the start of sampling was completed.

\section{Completed reports:}

Staubitz, W. W., Surface, J. M., Steenhuis, T. S., Peverly, J. H., Lavine, M. J., Weeks, N. C., Sanford, W. E., and Kopka, R. J., 1989, Potential use of constructed wetlands to treat landfill leachate, in Hammer, D. A., ed., Constructed wetlands for wastewater treatment: Chelsea, Mich., Lewis Publishers, p. 745-742. 
Period of project: October 1988 through September 1989

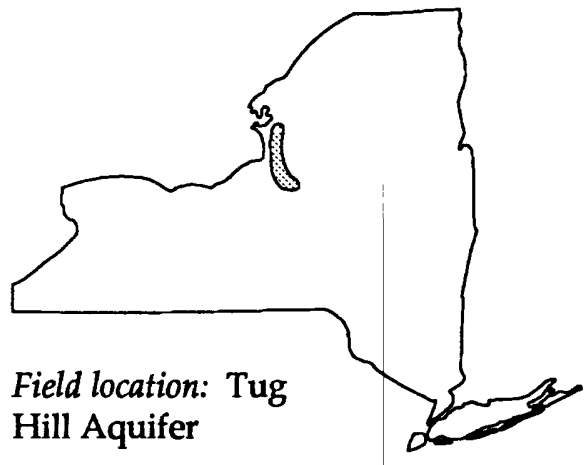

Project leader: Phillip J. Zarriello
Cooperating agencies: Temporary State Commission on Tug Hill

Problem: Ground water supplies 12 percent of the fresh water in New York State. By 1978, contamination had forced the closure of 120 public-supply wells. Ground-water supplies must be safeguarded to ensure adequate water for present and future needs. To achieve this goal, the source of water to a well must be defined.

Objective: To define the source of water (contributing area) of major public water supplies in the Tug Hill aquifer and to compare methods for delineating contributing areas.

Approach: To define the contributing areas of six municipal water supplies in the Tug Hill aquifer through geohydrologic information from previous studies. At Lacona-Sandy Creek, the contributing area will be defined through two analytical methods: (1) the modified uniform flow and the modified nonequilibrium flow method, and (2) a two-dimensional numerical flow model coupled with a particle-tracking program. Results will be compared, and additional comparisons will be made with results obtained through the "fixed radius" method.
Progress and significant results: Contributing areas for water supplies ranged from 0.01 to $1.0 \mathrm{mi}^{2}$ (square miles) and up to an additional $17 \mathrm{mi}^{2}$ of adjacent uplands that contribute recharge as a result of stream infiltration and direct runoff. The numerical methods indicated that most water pumped by the LaconaSandy Creek wells is diverted from springs and evapotranspiration along the western flank of the aquifer. High pumping rates and low recharge rates may may induce minor amounts of infiltration from Little Sandy Creek. Flow-path analysis shows that the size and shape of the contributing area is significantly different from the area of influence. Analytical methods, although easier to apply, have restrictive limiting assumptions that were not fully met in this aquifer. Despite this, the nonequilibrium method produced results similar to those obtained through the numerical methods; the uniform-flow method did not. Choice of delineation technique will depend on the resources available and the degree of accuracy required. Despite the uncertainties and incomplete information on the factors that affect the contributing area to a well, the methods used in this study provide a more reliable estimate of the contributing area than the commonly used "fixed radius" method. 


\section{Contributing Areas to Public Water-Supply Wells and Flow Paths from Contaminant Sources in the Glacial-Drift Aquifer at Cortland \\ (NY 89-184)}

Period of project: June 1989 through September 1992

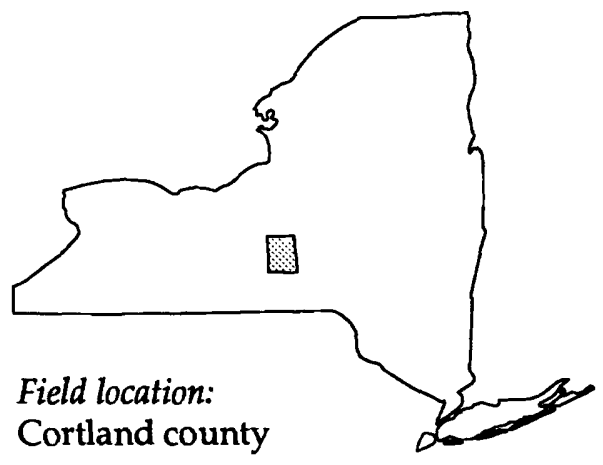

Project leader:

Todd S. Miller

\section{Cooperating agency: Cortland County Health Department}

Problem: Glacial-drift aquifers are principal sources of water for many communities in upstate New York. The high permeability of these aquifers and the shallow depth to the water table make them highly susceptible to contamination from a variety of sources. The City of Cortland and the surrounding communities are dependent on ground water from one of the highly productive glacial aquifers in upstate New York. Several parts of the aquifer have been contaminated by solvents and degreasers, gasoline, bacteria from failing septic systems, and leachate from hazardous-waste sites.

Objective: (1) To estimate the zones of contribution and traveltimes to public water-supply wells. (2) To determine the extent of the contamination plume and the general water quality of the aquifer with emphasis on organic chemicals. (3) To estimate ground-water flow paths from potential and known sources of contamination to the discharge areas.

Approach: A three-dimensional ground-water flow model will be developed and coupled to a particle-tracking routine to simulate the flow paths and traveltimes. Various surface geophysical surveys of the study area will be completed, such as seismic-refraction and marine seismic-reflection techniques to determine and delineate the stratigraphy of the geologic deposits that form the aquifer. Test holes will be drilled to (a) determine stratigraphy, (b) measure water-table elevations, and (c) collect water-quality samples from the aquifer. The samples will be analyzed for purgeable organic compounds and several inorganic constituents.

Progress and significant results: Water-level measurements were obtained and continued on a monthly basis. The conceptual groundwater flow model has been formulated, and the available well data were compiled, and organized into a data base for use with the numeric model.

Plans for next year: The construction and calibration of the three-dimensional groundwater flow model will continue through fiscal year 1990. Monthly water-level measurements will continue as well as data collection by two water-level recorders. Test-hole drilling will be completed, and hydrogeologic data will be compiled and interpreted. 


\section{Hydrogeology of Tributary Valleys and Uplands in Chenango County (NY 89-187)}

Period of project: June 1989 through March 1991

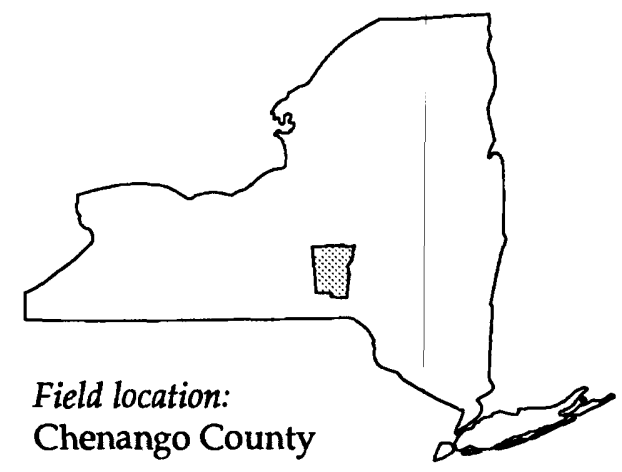

Project leader: Wendy S. McPherson

Cooperating agency: Chenango County Department of Planning

Problem: The till-mantled, bedrock uplands and tributary valleys of Chenango County are being considered for municipal and low-level radioactive-waste-disposal sites. Minimal information is available concerning the geologic framework and the ground-water flow systems in these regions. Chenango County needs a hydrogeologic data base that will provide information necessary to manage ground water and to protect ground-water quality.

Objective: (1) To develop a hydrogeologic data base that will include maps of well locations, aquifer boundaries, and thickness of unconsolidated material. (2) To create a preliminary geographic information system (GIS) for storing, managing, and displaying geographic and hydrogeologic data.

Approach: The hydrogeologic study involves collecting and examining well data from the entire county. Sources of data include local well drillers (domestic wells), New York State Department of Health (public water supplies), New York State Department of Transportation (test borings), New York State Department of Environmental Conservation (waste-disposal sites), and New York State Electric and Gas (gas wells). Well sites will be identified and plotted on base maps with the latitude, longitude, and altitude. Hydrogeologic data will be entered into the Survey's GWSI computer data base (Ground-Water Site Inventory). Well-location, aquifer-boundary, and unconsolidated-thickness maps will be developed from the hydrogeologic data. GIS coverages will be created and used as an integral part of the data-collection and analysis process.

Progress and significant results: The base maps were selected and are being drafted. Information on domestic wells has been collected from well drillers, and locations have been derived from tax records and maps. All available testboring data for Chenango County have been collected from the New York State Department of Transportation. Entry of well data into GWSI has begun. An annotated outline of the final report has been drafted and is in review.

Plans for next year: To continue to collect, locate, digitize, and enter well information into GWSI. Well location, aquifer delineation, and unconsolidated-aquifer-thickness maps will be drafted, and a well-inventory table will be created. The final report will be written. 


\section{Hydrologic Models, Long Island \\ (NY 84-125)}

Period of project: October 1983 through September 1990

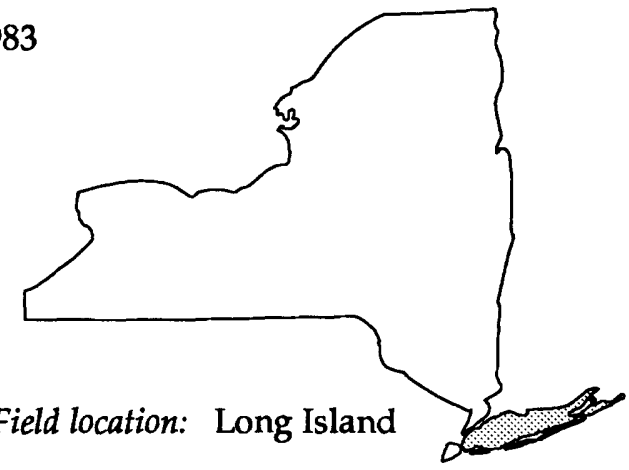

Project Chief:

Steven M. Feldman

Cooperating agencies: Nassau County Department of Public Works; Suffolk County Department of Health Services; Suffolk County Water Authority

Problem: Declining ground-water levels, streamflow depletion, saltwater encroachment into aquifers, and pollution from industrial and domestic wastes pose a serious threat to the potable water supply of Long Island. Integral to water-resource-management planning is an adequate knowledge of the hydrologic system and the testing of various management alternatives through predictive hydrologic models.

Objective: To provide quantitative estimates of (a) the characteristics of the ground-water system under predevelopment conditions, (b) the changes in these characteristics that have been induced by man, and (c) the changes that would result from implementation of various water-resources management schemes. Pertinent characteristics of the ground-water system include the patterns and rates of ground-water movement and the rates of ground-water discharge at boundaries (streams, shore, subsea discharges).

Approach: A new three-dimensional, finitedifference ground-water flow model that includes all unconsolidated hydrogeologic units on Long Island will permit regional hydrologic simulations. Data compilation and analysis for model input include estimates of gaged- and ungaged-stream base flow, current reinterpretation of hydrogeologic geometry, approximation of the saltwater-interface position, and refined calculation of ground-water recharge under natural and urbanized condition. Steady-state simulations of both predevelopment and recent hydrologic conditions and a transient-state simulation of the 1960's drought will be made and results compared with historical data to demonstrate the accuracy of the model. The simulations will add to our understanding of the ground-water system. Predictive runs will be made to assess various development stategies.

Progress and significant results: A three-dimensional flow model was used to assess various effects of proposed stream augmentation on the ground-water system . Pumping wells were simulated at interstream locations, and water was piped to various locations, where it was discharged to stream segments.

Plans for next year: To keep the model available to answer cooperator requests, and to finish all reports.

\section{Completed reports:}

Buxton, H. T., Smolensky, D. A., and Shernoff, P. K., 1989, Hydrogeologic correlations of selected wells on Long Island, New Yorka data base with retrieval program: U.S. Geological Survey Water-Resources Investigations Reports 86-4318, 107 p. 


\section{Hydrologic Atlas, Long Island}

(NY 83-132)

Period of project: April 1983 through September 1990

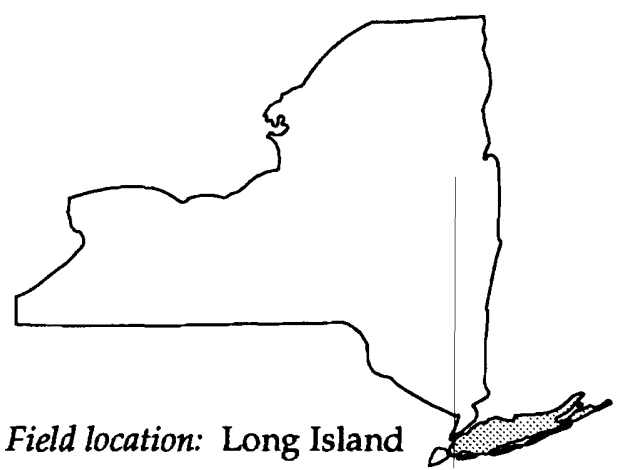

Project chief:

Kenneth A. Pearsall
Cooperating agency: New York State Department of Environmental Conservation

Problem: Effective management of the development of Long Island's freshwater resources is vital in view of past water-use trends and projected increases in consumptive water use. Until now, the "safe yield" concept has been fundamental to water-resources management on Long Island. The complexity of Long Island's hydrologic system makes the allowable withdrawal rates impossible to determine before formulation of a specific development plan; however, an alternative management approach has been presented that is based on (a) defining pertinent aspects of the present hydrologic condition on a regional scale, and (b) identifying areas most susceptible to unsuitable hydrologic effects.

Objective: (1) To compile all hydrologic data pertinent to water-resources management in a readily useable format. (2) To publish a regional hydrologic interpretation of these data periodically. (3) To reevaluate the regional monitoring networks and recommend augmentation as needed. (4) To demonstrate the feasibility, practicality, and advantage of a technically based water-resourcemanagement policy by making available and demonstrating the usefulness of pertinent interpretive hydrologic data.

Approach: A sequence of maps will be developed that demonstrate a hydrologic interpretation of data collected in regional monitoring networks. These will include: (1) a standard base map and topographic base map at scales of $1: 125,000$ and $1: 62,500,(2)$ hydrogeologic maps showing structure contours, lines of equal formation thickness, and cross sections through Long Island aquifers, (3) hydrologic maps showing potentiometric-surface altitudes, streamflow data, and water transmitting property, and (4) water-quality maps showing concentrations of chloride, nitrate, and selected organic compounds.

Progress and significant results: Technical assistance to NYSDEC (New York State Department of Environmental Conservation) continues for the implementation of the groundwater management plan for Long Island and for the Long Island well-permit program. The project is proceeding on schedule.

Plans for next year: To continue data collection and maintain an active technical role in the NYSDEC'S development of the Long Island ground-water management plan. 


\section{Hydrologic Atlas, Long Island \\ (NY 83-132 continued)}

Completed reports:

Nemickas, B., Mallard, G. E., and Reilly, T. E., 1989, Availability and historical development of ground-water resources of Long Island, New York-an introduction: U.S. Geological Survey Water-Resources Investigations Report 88-4113, 43 p.

Simmons, D. L., 1989, Depth to the water table on Long Island, New York, in March
1979: U. S. Geological Survey Water-

Resources Investigations Report 88-4151, 2 sheets, 1:125,000 scale.

Soren, Julian, and Simmons, D. L, 1987, Thickness and hydrogeology of aquifers and confining units below the upper glacial aquifer on Long Island, New York: U.S. Geological Survey Water-Resources Investigations Report 86-4175, 3 sheets, scale 1:125,000 . 


\section{Salt Water in Nassau County \\ (NY 84-147)}

Period of project: October 1984 through September 1989

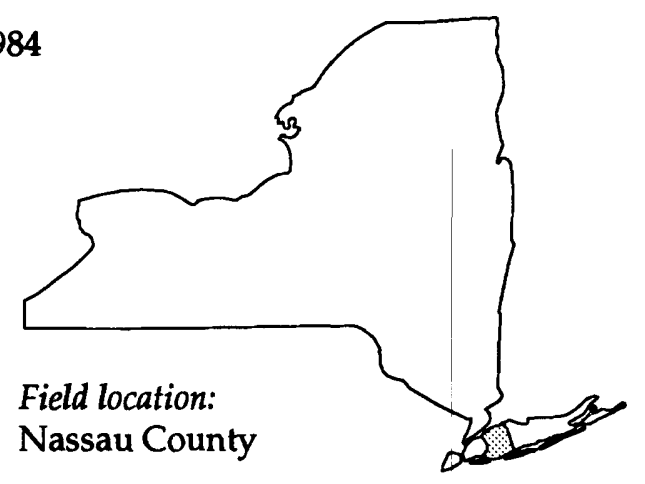

Project leader:

Stephen A. Terraciano
Cooperating agency: Nassau County Department of Public Works

Problem: All of the water supply for Nassau County is obtained from wells. Saltwater encroachment is one of the greatest threats to this water supply, especially under the barrier islands, where a confined aquifer is threatened by downward movement of saltwater through the confining layer and landward movement of the saltwater front. Integrated planning strategies are needed for all four aquifers in Nassau County. Consequently, saltwater intrusion necessitates reevaluation of Nassau County's south shore to assess the effects of heavy pumping in recent decades.

Objective: (1) To inspect and recondition outpost wells on the south shore. (2) To delineate the present position of the saltwater interface in each aquifer. (3) To investigate the phenomenon of saltwater movement, both vertically and horizontally, in Nassau County, and present the data in a serviceable format for water-supply managers.

Approach: (1) To evaluate all available data in regard to the saltwater interface in each of the four aquifers. (2) To recondition and sample outpost wells. (3) To install new observation wells and analyze water in all wells with attention to sampling depth. (4) To construct chloride maps and vertical sections for each aquifer.

Progress and significant results: Indications are that, although ground-water flow rates are low, landward movement of salty groundwater over the last 30 years is evident. The project is proceeding on schedule.

Plans for next year: To evaluate all hydrogeologic and water-quality data collected from present and newly drilled wells. To draft and construct maps and illustrations from data collected and complete the final report. 
Period of project: April 1984 through September 1990

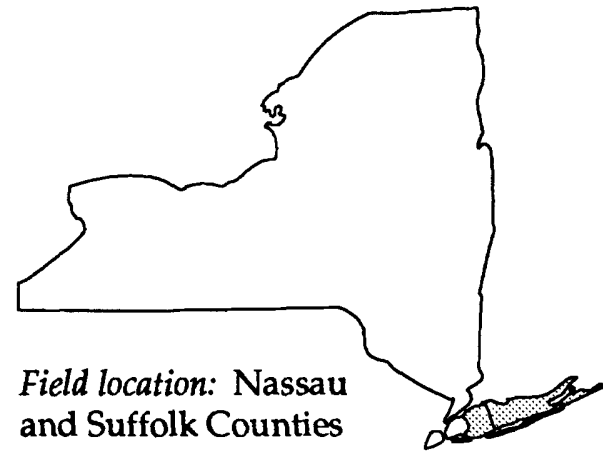

Project leader: Stephen J. Cauller
Cooperating agencies: Nassau County Department of Health; Suffolk County Department of Health Services; Suffolk County Water Authority

Problem: The hydrogeologic setting and landuse characteristics of Long Island provide a unique location for a water-quality appraisal because ground water serves 2.6 million people. The significance of ground water as a source of public water supply has grown sharply in the past few years, but contamination of this resource has restricted its use in many areas. Successful management of ground-water resources requires a thorough accounting of the present quality of ground water, and the nature and extent of groundwater contamination.

Objective: (1) To assess the quality of Long Island's ground-water resources by investigating the nature and extent of contamination in major land-use areas. (2) To present pertinent hydrologic and water-quality data to help in the evaluation and management of Long Island's ground-water resources and contamination problems.

Approach: (1) Assemble current and historical water-quality data. (2) Inventory and classify contaminants. (3) Define areal and crosssectional distributions of identified contaminants. (4) Correlate land-use patterns and hydrogeologic characteristics with patterns of contamination. (5) Provide graphic semiquantitative representation of contaminant extent for identified classes of contaminants. (6) Develop well networks and water-qualitysampling protocols to provide the data needed for addressing the objectives. (7) Investigate shallow ground-water quality in areas of distinct and singular land-use effects.

Progress and significant results: (1) Defined a statistical relation between the occurrence of volatile organic compounds in shallow ground water and pertinent variables (population density and land use) that represent the degree of urbanization. (2) Completed statistical analysis of major inorganic ions, inorganic trace elements, volatile organic compounds, organic compounds, and five groups of pesticides in five land-use areas.

Plans for next year: A statistical analysis will be performed to determine the relation 
between land use and power consumption and ground-water quality. Any temporal variation in chemical constituents over a 1year period will be evaluated. Interpretive data reports will be completed.

\section{Completed reports:}

Eckhardt, D. A. and Helsel, D. R., 1988, Statistical methods for regional groundwater-quality appraisal in different landuse areas, Long Island, New York, in Abstracts of Papers: American Chemical So- ciety, 196th national meeting; p. ENVR 2.

Eckhardt, D. A., Siwiec, S. F., and Cauller, S. J., 1989, Regional appraisal of ground-water quality in five different land use areas , Long Island, New York in Mallard, G. E., and Ragone, S. E., eds., U. S. Geological Survey Toxic Substances Hydrololgy Program-Proceedings of the Technical Meeting, Phoenix, Arizona, September 26-30, 1988: U.S. Geological Survey Water-Resources Investigations Report 88-4420, p. 397-403. 


\section{Selected Topics in Ground-Water Geochemistry on Long Island (NY 85-153)}

Period of project: January 1985 through September 1989

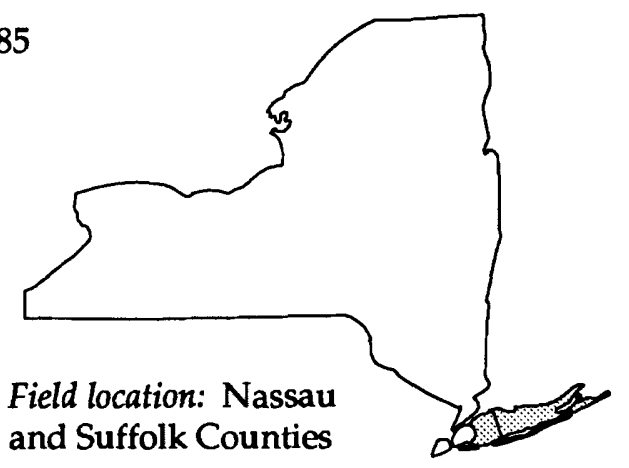

Project leader: Kenneth A. Pearsall
Cooperating agencies: Nassau County Department of Public Works; Suffolk County Department of Health Services; Suffolk County Water Authority

Problem: Natural geochemical processes operating on Long Island's ground-water system lack adequate study and understanding. A basic understanding of these processes, especially those that operate in anaerobic ground-water environments, is essential to predict the fate of contaminants such as VOCs (volatile organic compounds) that enter the ground-water system.

Objectives: To expand current knowledge of Long Island's aquifer system and its anaerobic environments by (a) developing a geochemical-reaction model of the evolution of the major-ion character of the water, (b) investigating in detail the geochemistry of anaerobic environments in the ground-water system, and (c) examining how and to what extent natural geochemical processes are affected by the introduction of contaminants, and (d) investigating how geochemical processes affect the attenuation of contaminants.
Approach: A two-phase study will examine the evolution of water quality in several different geochemical environments. The first phase will evaluate the evolution of native (natural) water quality in the aerobic environments that predominate in Long Island's aquifer system; the second will examine geochemical reactions in reducing environments. The geochemical speciation models WATQEF, BALANCE, and PHREEQE will be the principal tools used to evaluate the processes.

Progress and significant results: The project is complete. Native water quality in aerobic and nonaerobic environments in the major aquifer has been defined. The principal natural process affecting ground-water quality on Long Island is the oxidation of dissolved and solid-phase organic matter into the aquifer system and the coincidental consumption of oxidizers. The introduction of organic contaminants into the aquifer system hastens the shift from aerobic to anaerobic conditions and amplifies the severity of the change.

Plans for next year: To publish the final report. 


\section{Pumping Centers on Long Island}

(NY 85-155)

Period of project: October 1984 through September 1990

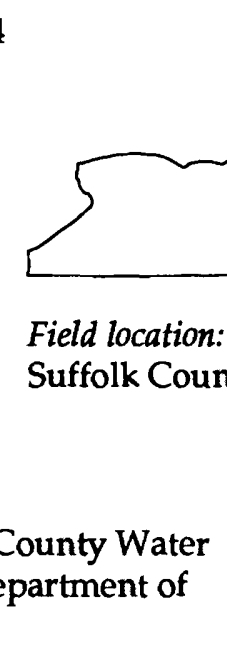

Cooperating agencies: Suffolk County Water Authority; Suffolk County Department of Health Services

Problem: Ground water, the sole source of water for Suffolk County, is administered by the Suffolk County Water Authority from an extensive network of well fields or pumping centers. Increased pumpage and toxic waste have expanded the potential for ground-water contamination, and production wells in Queens and Nassau Counties have been closed as a result. Detailed knowledge of ground-water flow patterns near pumping centers is needed (1) to help water-resource managers maximize withdrawals and minimize potential contamination at a particular well field and (2) for the design and selection of future pumping-station locations.

Objective: To provide hydrogeologic information that will support effective water-resources management. Suffolk county will be divided into several different hydrogeologic environments according to physiographic location, stratigraphy, and hydrogeologic characteristics. Information obtained from individual sites will be applied to other sites within the same hydrogeologic environment.

Approach: Two pumping centers in differing hydrogeologic environments will be selected for detailed study according to physiography and geologic and hydrologic conditions. A pumping test will be performed on one or two
Project leader:

Richard A. Cartwright production wells at each pumping center. The pumping-test data will be analyzed through analytical methods, curve-matching techniques, and a radial-flow model to define aquifer characteristics. Results will be used to delineate the zone of contribution for each production well.

Progress and significant results: Pumping tests were performed at the Long Springs Road pumping station in Southampton and the Thomas Street pumping station in Bay Shore. These sites represent a "freshwater bubble" environment and a "south-shore confined environment," respectively. Data analysis indicated average hydraulic conductivity values for each site. The conductivity from the Long Springs Road site (representing unconfined conditions) was used to calculate the zone of contribution for a hypothetical well in that area. This is more accurate than calculating from islandwide conductivity averages given in published reports. Application of this technique to each of the other hydrogeologic environments will improve the effectiveness of water-resources-management strategies. Pumping-test results from areas under confined conditions yielded site-specific conductivity values that aid in water-resource management, but the zone of contribution cannot be delineated for confined conditions at present.

Plans for next year: To complete the final report. 


\section{Contaminant Transport in Two Aquifers \\ (NY 86-159)}

Period of project: October 1985 through September 1989

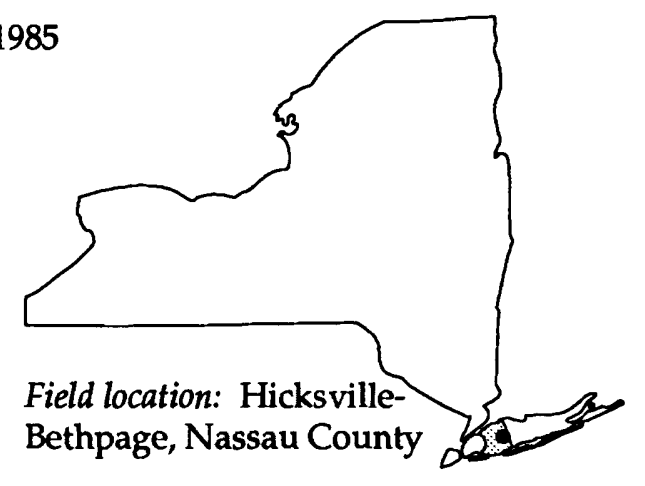

Project leader:

Douglas A. Smolensky,
Cooperating agency: Nassau County Department of Health

Problem: Ground water is the sole source of public supply for Nassau County. Groundwater contamination has increased with increasing residential and industrial development. The upper glacial (water-table) aquifer is no longer a source of public supply, and the Magothy aquifer, which is in direct hydraulic contact with it, has shown isolated increases in organic contamination. To sustain the Magothy as a potable source, the mechanisms that control contaminant movement between aquifers must be fully understood and point sources defined and delineated.

Objective: To define ground-water flow paths and contaminant transport in a highly developed multi-aquifer system by (1) delineating (a) patterns of ground-water movement in the study area, (b) areas showing the highest concentrations of contaminants, and (c) the extent of contamination; (2) documenting ground-water conditions as additional data are collected; (3) defining the three-dimensional ground-water flow paths; (4) documenting subsurface hydrogeologic conditions and the associated hydraulic properties; (5) evaluating the sensitivities of the mechanisms and stresses that influence contaminant transport.

Approach: To make a complete inventory of data (hydrogeologic, water-quality, water levels, etc.) for preliminary hydrologic assessment of the study area. Additional information from new wells and water-quality analyses will help define hydrologic conditions. A three-dimensional ground-water flow model will be developed to simulate the system geometry and produce a local water budget and refine the aquifer delineation. A three-dimensional particle-tracking model will be used to define flow paths and recharge areas and determine time-of-travel.

Progress and significant results: Particle tracking analysis was completed. Complex threedimensional flow paths were defined along with associated time of travel. The effect of large-scale pumping and artificial recharge on the transport of contaminants was determined.

Plans for next year: To complete the final report and keep the model available for the cooperator.

\section{Completed reports:}

Smolensky, D. A. and Feldman, S. M., 1990, Geohydrology of the BethpageHicksville-Levittown area of Long Island, New York: U. S. Geological Survey Water-Resources Investigations Report $88-4135,25$ p. 


\section{Cross-Sectional Analysis of Ground-Water Flow Patterns on Long Island (NY 86-160)}

Period of project: October 1986 through September 1989

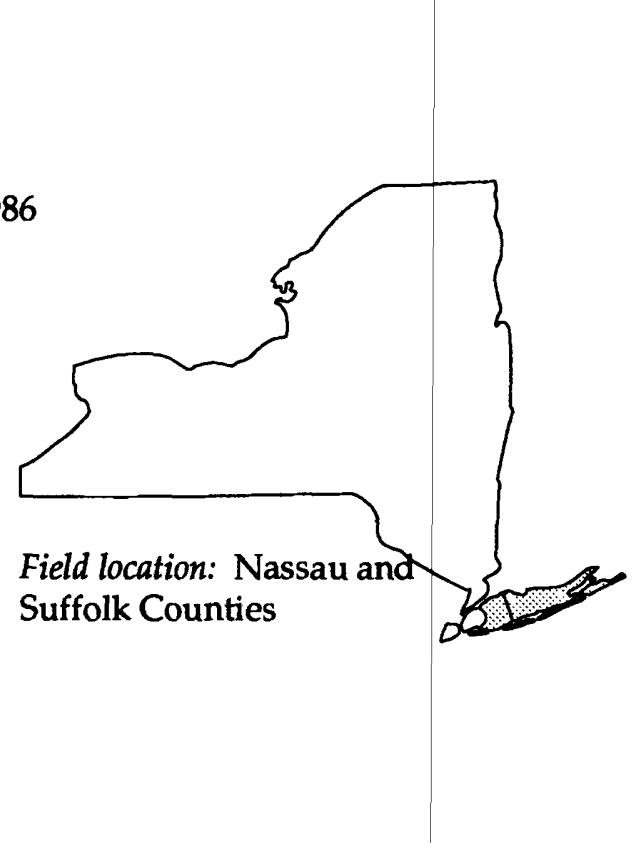

Project leader: Edward Modica
Cooperating agencies: Suffolk County Department of Health Services; Suffolk County Water Authority; Nassau County Department of Public Works

Problem: Understanding the nature of flow patterns is crucial to the investigation of many water-supply-related problems on Long Island. Point-source contamination on Long Island has become increasingly widespread. Contamination of upper aquifers has forced development of older, uncontaminated waters in deep aquifers. With this trend, increased concern for protection of deep aquifers has resulted in legislation to protect the recharge areas at land surface. This and many related problems require an understanding of the actual path a particle of water takes through the ground-water system.

Objective: To investigate the flow patterns and the transport of solutes in the Long Island ground-water system through flow-simulation techniques along a representative north-south cross section. The cross section lies along a flow line common to each of the major aquifers and will allow a realistic estimate of vertical flow patterns in the section. The knowledge gained from this section can be applied to other locations because of the symmetry of the Long Island ground-water system.

Approach: Phase I will address hydraulic considerations and advective transport. A cross-sectional ground-water flow model will be constructed, and stream-function analysis will be used to define flow patterns and travel times along the modeled section. Phase II will address the effects of dispersion and chemical transport in the cross section and will evaluate the distribution of nitrate and other constituents. The model will be used to assess the effects of contamination entering from several hypothetical sources.

Progress and significant results: Flow geometry, traveltimes, and velocity distribution were generated for the cross-sectional model of Long Island. From these were established: (1) paths and rates of ground-water flow from entry at the water table to the discharge point; (2) vertical distribution of flow among aquifers; (3) recharge area of confined aquifers, and (4) the age distribution of water. 


\section{Computer Applications onLong Island \\ (NY 86-162)}

Period of project: October 1985 through September 1989

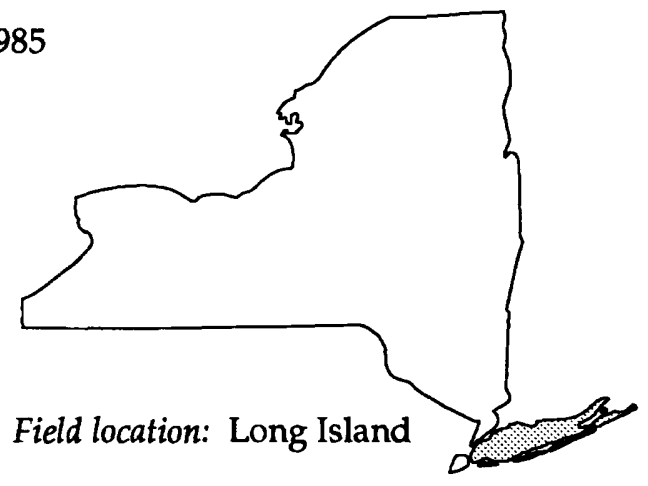

Project leader:

George W. Hawkins

Cooperating agencies: Nassau County Department of Public Works, Suffolk County Department of Health Services, Suffolk County Water Authority

Problem: The Long Island Subdistrict office maintains information on approximately 2,200 stormwater basins, 9,600 wells, 600 stream sites, and 13 precipitation sites with 215,000 water-level measurements and 118,900 waterquality samples. To deal with this large amount of data manually is impractical; thus specialized computer applications are often needed to fill the needs of a particular project.

Objective: (1) To develop, maintain, and enhance software that provides "user friendly" access to local data bases not provided by software from headquarters. (2) To assist project personnel in developing specialized computer applications or, where project personnel lack the necessary expertise, to undertake the complete development of these applications. (3) To provide program documentation and instruction in the use of the hardware and software. (4) To install and maintain computer software and peripherals acquired through national contracts or local purchases and monitor their use and plan new acquisitions.
Approach: Parts of the local data bases will be used to update the national data bases, where appropriate. When software provided by headquarters does not fulfill local requirements, additional applications will be developed. The need for additional applications may be identified by project personnel or by request of personnel from other projects. A GIS (Groundwater Information System) data base of digitized map data of the Long Island coastline and major physiographic features for the 7.5-minute quadrangles covering Long Island will be developed. Preparation of hydrologic data reports produced on a routine basis, specifically the monthly water-resources summary and the annual water-resources-data reports, will be automated where possible. Project personnel will monitor computer usage and gather user comments to determine office needs for additional hardware and software.

Progress and significant results: Local data bases containing water levels, hydrogeologic characteristics, recharge-basin characteristics, and recharge-basin infiltration rates were developed and supported. Local NWIS (National Water Information System) data bases containing information on surface-water and ground-water site data, water quality, and stream discharges were installed and supported. 


\section{Base-Flow Separation \\ (NY 86-163)}

Period of project: April 1988 through September 1989

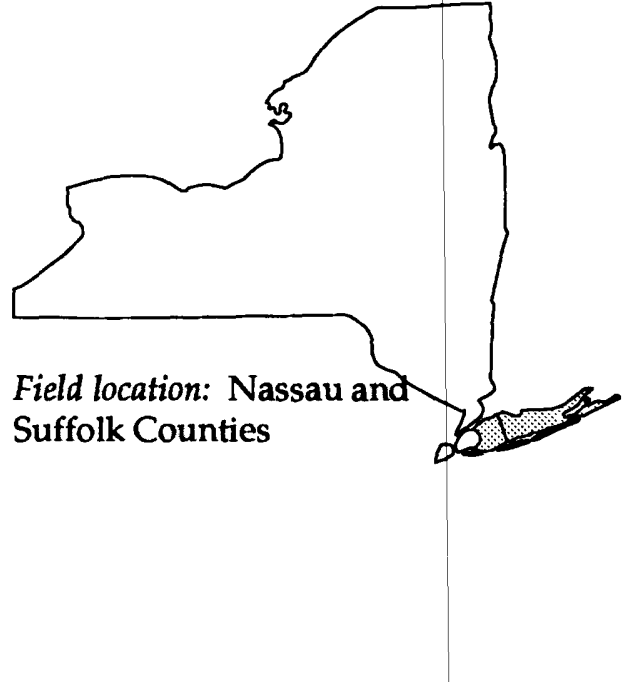

Project leader:

Anthony G. Spinello
Cooperating agencies: Suffolk County Department of Health Services; Suffolk County Water Authority; Nassau County Department of Public Works

Problem: Long Island streams function as ground-water drains. Relatively small declines in ground-water levels cause pronounced decreases in stream discharge. Progressive eastward urbanization on the south shore of Long Island has caused widespread decreases in ground-water recharge through (1) increase in impermeable land-surface area, (2) construction of storm sewers, and (3) sanitary sewers. Consequently, ground-water levels have declined, and ground-water discharge to streams in turn has waned. These 1970's changes have been documented. Since then, additional sanitary sewers have been installed and hook-ups are nearing completion. These transitional-period changes should be documented as equilibrium is approached.

Objective: (1) To calculate the percentages of base flow in selected south-shore streams during the past decade. (2) To analyze the effect of increased sanitary sewer usage on base flow in the past decade. (3) To evaluate the present status of streamflow with respect to the predicted equilibrium conditions.
Approach: Approximately 10 streams on the south shore of Nassau and Suffolk Counties with continuous-record gages will be chosen. Selected streams in Suffolk County will serve as an index of predevelopment conditions. Published hydrograph-separation techniques will be used to quantify base flow as a percentage of total streamflow for each stream through water year 1985. Flow-duration curves for selected streams will be prepared and analyzed . Double-mass curves of streams in selected areas will be assembled and analyzed to evaluate their status (transitional, equilibrium, or approaching equilibrium).

Progress and significant results: Base flow before development constituted about 95 percent of the total annual stream discharge, but in 1976-85, base flow averaged 14 percent in streams in a highly urbanized, sewered area; 79 percent in streams in a less urbanized, more recently sewered area; 88 percent in streams in a suburban area where sanitary sewering is not yet complete; and 96 percent in streams in an unsewered area where development is minimal.

Plans for next year: To complete the final report. 


\section{Advective Transport and Saltwater Influences on the North Fork of Long Island \\ (NY 88-172)}

Period of project: October 1987 through October 1990

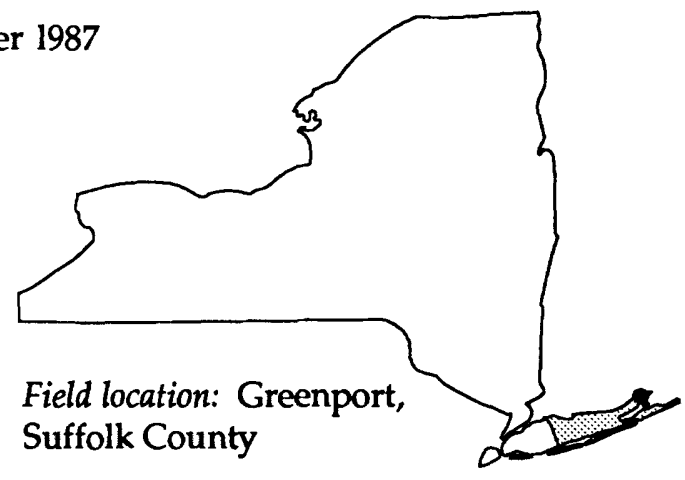

Project leader:

Elizabeth R. McNew
Cooperating agencies: Suffolk County Department of Health Services; Suffolk County Water Authority

Problem: Fresh ground water in the eastern part of Long Island's north fork is the sole source of water for the surrounding communities. Contamination from agricultural pesticides and fertilizers as well as saltwater intrusion threaten this resource. A detailed quantitative analysis of the flow system within the fresh ground-water system will provide the knowledge necessary to begin evaluating the fate of contaminants (other than saltwater) within the system. The system can be rigorously defined by delineating the flow of both freshwater and saltwater within a variabledensity system.

Objective: To define the features of this shallow freshwater flow system by investigating (a) the saltwater/freshwater interface, (b) the aquifer-material properties, and (c) the steady-state and transient stresses on the system. This information will enable the development of a numerical model of the flow system. Several progressively detailed approaches probably will be required. These efforts will be finalized in a comprehensive density-dependent numerical simulation of the study area.

Approach: The freshwater/saltwater system will be defined by (1) water-level readings and development of a water-table map, (2) waterquality measurements, (3) aquifer-parameter determination, (4) water-budget considerations such as rainfall/snowfall as input and pumping/discharge as outflow, and (5) incidental influences such as tidal and barometric variations that must be considered to prevent misinterpretation of data. Numerical simulation of the study area will require preliminary two-dimensional finite-difference modeling of the freshwater zone only. The preliminary modeling will help define boundary conditions for two-dimensional finite-element modeling of a density-dependent system. Verification and sensitivity of the developed model will be tested before results are accepted.

Progress and significant results: The scope of the project has been defined. Surface geophysics were conducted to investigate the spring and fall saltwater interfaces. New fresh- and saltwater wells were installed in the summer of 1989. A regular sampling plan has been implemented.

Plans for next year: Water-level and waterquality readings will be taken to further define the saltwater-interface location. Leveling, recorder installation, and downhole geophysics will be performed on new wells. Modeling is expected to begin, and the report will be started. 
Period of project: April 1988 through September 1990

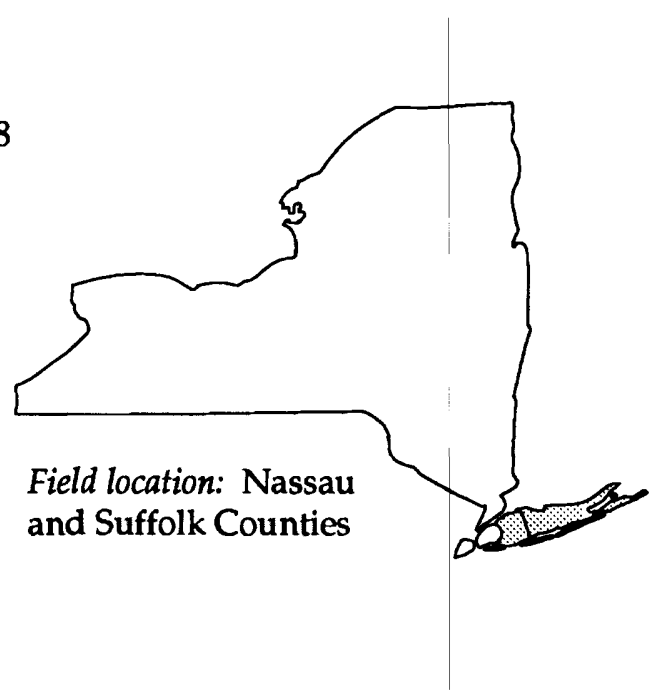

Project leader: Ralph J. Haefner
Cooperating agency: New York State Department of Environmental Conservation

Problem: NYSDEC (New York State Department of Environmental Conservation) is responsible for the management of the quality and quantity of ground water on Long Island. Currently NYSDEC must review various data sources in the form of maps and computer and paper files to assess spatial and proximal distribution of geographic, hydrologic, and manmade influences that may affect the water drawn through a proposed well. Since other agencies may store data in an incompatible format, environmental decisions may be made with inadequate data and (or) only through time-consuming efforts.

Objective: (1) To design and develop a GIS (Geographic Information System) data base from NYSDEC and USGS data. (2) To design a set of automated GIS computer programs to assess geographic, hydrologic, and manmade features that influence the siting of a well. (3) To evaluate and test the programs in a wide variety of applications.

Approach: (1) To develop a conceptual, then physical, design of the GIS data base. (2) To select a pilot study area containing a wide range of data complexity. (3) To prepare datasource maps for digitization. (4) To digitize data layers and check them for quality control. (5) To document data layers. (6) To develop computer programs to access the GIS data base, and conduct overlay and proximity analysis for features of hydrologic significance to aid in well siting. (7) To evaluate and test the programs. (8) To continue digitization beyond the pilot study area as time allows.

Progress and significant results: A pilot study area was selected that encompasses $162.55 \mathrm{mi}^{2}$ within six 7.5-minute quadrangles on eastern Long Island. This study area includes varying degrees of data intensity. Twenty-six data layers indicating the geographic, hydrologic, and manmade features within the study area were automated. The AML (ARC Macro Language) program, which accesses and retrieves the data, has been completed but it is still undergoing testing. The study area has been expanded to an area nearer the Nassau/ Suffolk County border, which has a greater degree of data density. Data automation will continue in this expanded area, which will allow further testing of the AML program.

Plansffor next year: (1) To complete automation of coverages within the study area, then extend to the remainder of Long Island as time permits. (2) To develop, evaluate, and test AML programs and complete the final report. 


\section{Analysis of Aquifer Vulnerability \\ (NY 88-177)}

Period of project: August 1988 through July 1989

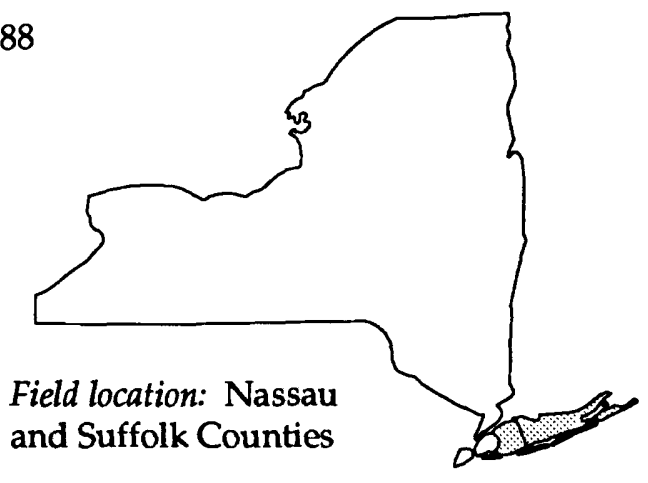

Project leader:

Steven F. Siwiec
Cooperating agency: Long Island Regional Planning Board

Problem: The Long Island Regional Planning Board has designated special ground-waterprotection areas on Long Island where highquality water recharges the deep sole-source aquifer system. To ensure an adequate water supply for future generations, ground-water quality must be preserved or improved. A thorough understanding of the effects of human development and aquifer characteristics on ground-water quality is essential to successful management and development of these areas.

Objective: (1) To develop methods that relate development factors and aquifer characteristics to ground-water quality. (2) To develop stochastic models to predict future groundwater quality from the derived relations and planned or hypothetical land development. (3) To compare recent water-quality data within the study area with predicted model results. (4) To examine ways to improve the models by using larger scale data and various data-aggregation techniques.

Approach: (1) Various independent explanatory variables related to human activities and hydrogeology will be characterized and loaded into a geographic information system. (2) Available ground-water-quality data will be inventoried. (3) Stochastic relations will be developed through maximum-likelihood logistic regression analysis. (4) Aquifer vulnerability and future contamination potential will be modeled through the use of these derived relations. (5) Maps will be generated to illustrate the predicted effects of various land-development scenarios on ground-water quality.

Progress and significant results: The project has been completed, and the final report is in progress.

Plans for next year: To prepare maps showing study results and complete the final reports.

\section{Completed report:}

Siwiec, S. F., and Stackelberg, P. E., 1989, Relating ground-water quality to land use-considerations of scale and data resolution [abst.], in Pederson, G. L., and Smith, M. M., eds., U. S. Geological Survey second national symposium on water quality - abstracts of the technical sessions, Orlando, Florida: U. S. Geological Survey Open-File Report 89-409, p. 90-91. 
Period of project: October 1988 through September 1992

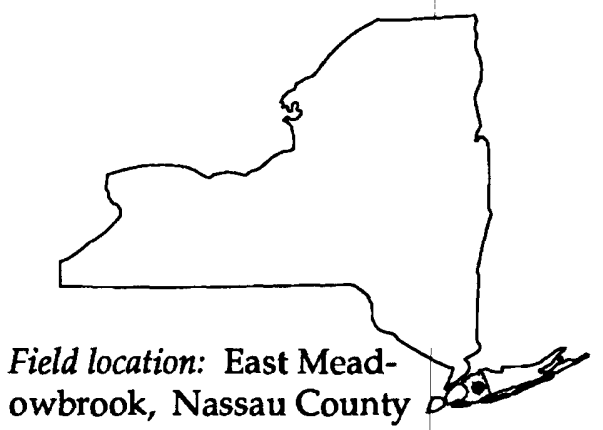

Project leader:

Henry F. H. Ku
Cooperating agency: Nassau County Department of Public Works

Problem: Urbanization has caused a decline in the water table as a result of the installation of sanitary sewers, the increased discharge of storm runoff to streams, and increased pumpage. In turn, base flow has been decreased, streams have been shortened, wetland area has been diminished, and the amount of fresh ground water has decreased. The expanded paved area has increased peak discharges of streams and bacteria loading into the surrounding bays. The diversion of storm runoff to streams decreases recharge and thus further lowers the water table.

Objective: (1) To evaluate the hydrologic and water-quality effects of stream-channel modification in urban streams. (2) To quantify changes in peak flow and in bacterial and chemical loads as stormflow passes through stream-modification structures. (3) To examine how changes in ground-water levels influence the relations between stream and aquifer. (4) To determine how to efficiently lengthen streams and increase recharge.

Approach: To select two urban streams with perennial base flow that receive routed storm runoff and have extensive historical data. Historical discharge records and water-quality data will be examined, and discharge will be measured during storms and dry weather. Water-table altitudes will be monitored after installation of flow-modification structures. A three-dimensional ground-water-flow model of the stream channels and surrounding area will be developed.

Progress and significant results: Analysis of the effects of impervious surface area on rainfallrunoff relations reveals good correlation. The total impervious surface area that carries storm runoff into the headwaters of East Meadow Brook was calculated. Stormflow volume and recharge are being analyzed regularly. Quarterly sampling of ground water from wells in the headwater study area and regular sampling of stormflows continues. A water-quality minimonitor was installed at East Meadow Brook to measure temperature, specific conductance, and $\mathrm{pH}$. Geophysical logging of the well network was completed, and correlations and interpretations are underway. Monthly water levels were formatted as water-table maps of the regional and headwaters study area.

Plans for next year: To continue water-level measurements, volume-recharge analysis of stormflow data, and stormflow and groundwater sampling. A priority will be discharge measurement by dye-dilution techniques to complete the data analysis of stages greater than 3.5 feet (present limit of direct measurements). Additional equipment and monitoring will be needed to determine changes in water quality and the amount of recharge at East Meadow Brook after stream modification. 


\section{Migration of Contaminants by Advective Transport \\ Beneath a Waste-Disposal Site \\ (NY 89-183)}

Period of project: October 1988 through September 1992

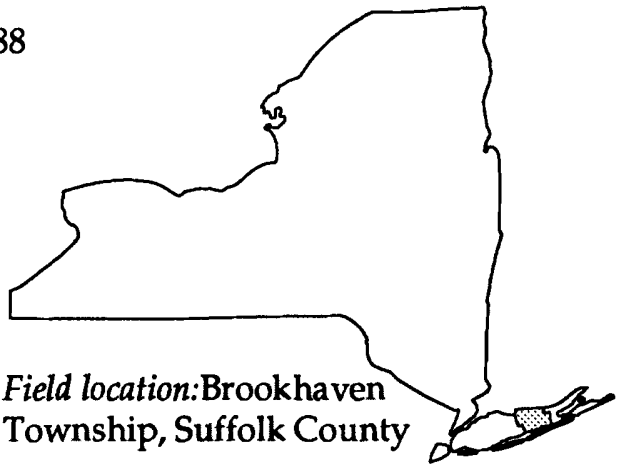

Project leader: Steven M. Feldman

Cooperating agency: Town of Brookhaven, Department of Waste Management

Problem: The vertical migration of leachate in ground water beneath the Horseblock Road landfill in Brookhaven requires further investigation to assess the ramifications of a previous two-dimensional solute-transport modeling study to predict plume migration. Current knowledge of water quality, hydraulic gradients, and local hydrogeology is insufficient to determine the depth and extent to which contaminants have migrated into the ground-water system.

Objective: (1) To define the lateral and vertical extent of the plume from field observations.

(2) To evaluate the reliability of the previously developed two-dimensional solute-transport model. (3) To improve our understanding of the mechanisms that control the vertical migration of contaminants in the landfill vicinity.

Approach: Additional wells will be installed and sampled to define the horizontal and vertical extent of the plume, and the observed plume migration will be compared to predictions that were made with the two-dimensional solute transport model. A three- dimensional ground-water flow model will be developed to more accurately determine local flow patterns, and a particle- tracking postprocessing routine will then be used to generate distinct flow paths and traveltime data.

Progress and significant results: Fourteen wells were installed to provide more detailed spatial water-quality and water-level data. Recent data indicate that the leachate plume has increased horizontally, is more than 110 feet below the water table in the vicinity of the landfill, and has caused elevated concentrations of inorganic constituents in nearby Beaverdam Creek. The completed ground-water flow model simulates small-scale hydraulic gradients beneath the landfill and the effect that the Gardiners Clay confining unit and Carmens River have on local ground-water flow patterns.

Plans for next year: A particle-tracking, postprocessing program will be used to analyze the advective transport and traveltime of leachate that enters the ground-water system beneath the landfill. The area of contribution to nearby Beaverdam Creek will also be delineated. 


\section{NEW YORK DISTRICT STAFF}

1989-90

District Chief

Assistant District Chief

Administrative Services Section

Albany Subdistrict Office

Hydrologic Records Unit

Potsdam Field Office

Hydrologic Studies Section

Long Island Subdistrict Office

Hydrologic Studies Section

Environmental Quality and

Hydrologic Records Section

Hydrologic Data Assessment/

Information Management Section

Ithaca Subdistrict Office

Hydrologic Data Section

Hydrologic Studies Section
L. Grady Moore

Vacant

Carol L.Woodward

John R. Ritter

Gary Firda

Howard C. Lent

Leonard R. Frost

Bronius Nemickas (Acting)

Bronius Nemickas

Edward T. Oaksford

Kenneth A. Pearsall

Robin G. Brown (Acting) James Campbell Robin G. Brown 


\section{REPORTS PUBLISHED OR RELEASED MAY 1988-SEPTEMBER 1989}

Barnes, C. R., 1988, Relation of long- and shortterm atmospheric sulfur concentrations to sulfate deposition in New York State:

Northeastern Environmental Science, v. 6 , no. 2,1987 , p. 89-98.

Bingham, D. L., 1988, U.S.Geological Survey ground-water studies in New York: U.S. Geological Survey Water Fact Sheet, Open-File Report 88-108, 2 p.

Bubeck, R. C., and Burton, R. S., 1989, Changes in chloride concentrations, mixing patterns, and stratification characteristics of Irondequoit Bay, Monroe County, New York, after decreased use of road-deicing salts, 1974-84: U.S. Geological Survey Water-Resources Investigations Report $87-4223,52$ p.

Bugliosi, E. F., 1988, Potential yields of wells in unconsolidated aquifers in upstate New York-lower Hudson sheet: U.S. Geological Survey Water-Resources Investigations Report 87-4274, 1 sheet, scale 1:250,000.

Bugliosi, E. F., and Trudell, R. A., 1988, Potential yields of wells in unconsolidated aquifers in upstate New York-Adirondack sheet: U.S. Geological Survey Water-Resources Investigations Report $87-4276,1$ sheet, scale 1:250,000.

Bugliosi, E. F., Trudell, R. A., and Casey, G. D., 1988 , Potential yields of wells in unconsolidated aquifers in upstate New YorkHudson-Mohawk sheet: U.S. Geological Survey Water-Resources Investigations Report 87-4275, 1 sheet, scale 1:250,000.

Buxton H. T., and Modica, Edward, 1989, Pattern and rate of ground-water movement on Long Island, New York [abst.], in Abstracts with Programs: Geological
Society of America, Northeastern Section, p. 7, no. 15232.

Buxton, H. T., Smolensky, E. A., and Shernoff, P. K., 1989, Hydrogeologic correlations for selected wells on Lond Island, New York-a data base with retrieval program: U.S. Geological Survey Water-Resources Investigations Report 86-4318, 107 p.

Casey, G. D., and Reynolds, R. J., 1989, Hydrogeology of the stratified-drift aquifers in the Utica area, Oneida County, New York-part 1 (west): U.S. Geological Survey Water-Resources Investigations Report 88-4194, 8 sheets, scale 1:24,000.

1989, Hydrogeology of the stratified-drift aquifers in the Utica area, Oneida and Herkimer Counties, New York-part 2 (east): U.S. Geological Survey WaterResources Investigations Report 88-4195, 8 sheets, scale 1:24,000.

1989, Hydrogeology of the stratified-drift aquifers in the Rome area, Oneida County, New York: U.S. Geological Survey Water-Resources Investigations Report 88-4155, 8 sheets, scale 1:24,000.

Eckhardt, D. A. V., Flipse, W. J., Jr., and Oaksford, E. T., 1989, Relation between land use and ground-water quality in the upper glacial aquifer in Nassau and Suffolk Counties, Long Island, New York: U.S. Geological Survey Water Resources Investigations Report 86-4142, 35 p.

Eckhardt, D. A. V., and Pearsall, K. A., 1989, Chlorinated organic compounds in ground water at Roosevelt Field, Nassau County, Long Island, New York: U.S. Geological Survey Water-Resources Investigations Report 86-4333, 62 p. 


\section{REPORTS PUBLISHED OR RELEASED \\ MAY 1988-SEPTEMBER 1989 \\ (continued)}

Hahl, D. C., 1988, Effects of proposed emergency withdrawals from the Hudson River by the City of New York on saltfront migration in the Hudson River estuary-Legal testimony given before Judge Susan Dubois, 1988: U.S. Geological Survey Open-File Report 88-315, 10 p.

Irwin, D. J., 1988, Thickness and potential well yield of the stratified deposits in the Croton River basin, Putnam County, New York: U.S. Geological Survey WaterResources Investigations Report 87-4129, 3 sheets, scale 1:24,000.

Kappel, W. M, 1989, A Study of the hydrogeology of the Niagara Falls area [Abst.], in Abstracts with Programs: Geological Society of America, Northeastern Section, p. 25 , no. 8661 .

Marshall, M. P., and Finch, A. J., 1988, WaterResources activities in New York, 1987-88. U.S. Geological Survey Open-File Report $88-94,55 \mathrm{p}$.

Miller, T S., 1988, Potential yields of wells in unconsolidated aquifers in upstate New York-Niagara sheet: U.S. Geological Survey Water-Resources Investigations Report 88-4076, 1 sheet, scale 1:250,000.

Miller, T. S., and Krebs, M. M., 1988, Groundwater availability in the central part of Lake Ontario basin, New York: U.S. Geological Survey Water-Resources Investigations Report 87-4183, 1 sheet, scale $1: 250,000$.

Paulsen, R. T., 1988, Radionuclides in groundwaters of the northeastern United States and southern Canada-a literature review and summary [abst.], in Program book with abstracts. Radon in the Northeastperspectives and geologic research: Troy, N.Y., Northeastern Science Foundation, p. 8.
Prince, K. R., Reilly, T. E., and Franke, O. L., 1989, Analysis of the shallow groundwater flow system near Connetquot Brook, Long Island, New York: Journal of Hydrology, v. 107, p. 223-250.

Prince, K. R., and Schneider, B. J., 1989, Estimation of hydraulic characteristics of the upper glacial and magothy aquifers at East Meadow, New York, by use of aquifer tests: U.S. Geological Survey Water-Resources Investigations Report 87-4211, 43 p.

Randall, A. D., Snavely, D. S., Holecek, T. J., and Waller, R. M., 1988, Alternative sources of large seasonal ground-water supplies in the headwaters of the Susquehanna River basin, New York: U.S. Geological Survey Water Resources Investigations Report 85-4127, 121 p.

Reynolds, R. J., 1988, Hydrogeology of the Croton-Ossining area, Westchester County, New York: U.S. Geological Survey Water-Resources Investigations Report 87-4159, 5 sheets, scale 1:24,000.

1988, Availability of ground water from unconsolidated deposits in the Mohawk River basin in southern Herkimer County, New York: Herkimer-Oneida Counties Water Resources Planning Report No. 1, 3 sheets, scale 1:24,000.

Rogers, R. J., 1988, New York ground-water quality, in Moody, D. W., Carr, J., Chase, E. B., and Paulson, R. W., eds., National Water Summary 1986-Hydrologic events and ground water quality: U.S. Geological Survey Water Supply Paper 2325 p. 385-392, [also U. S. Geological Survey Open-File Report 87-0742, 10 p.]

Simmons, D. S., 1989, Depth to the water table on Long Island, New York, in March 1979: U.S. Geological Survey Water-Resources 


\section{REPORTS PUBLISHED OR RELEASED \\ MAY 1988-SEPTEMBER 1989 \\ (continued)}

Investigations Report 88-4151, 2 sheets, scale $1: 125,000$

Snavely, D. S., 1988, Estimation, analysis, sources, and verification of consumptive water-use data in the Great Lakes - St. Lawrence River basin: U.S. Geological Survey Water Resources Investigations Report 88-4146, 28 p.

1988, Great Lakes Regional Water-Use Data Base - a water-resources management tool, in Waterstone, Marvin, and Burt, $R$. J., eds., Water-use data for water resources management: American Water Resources Association, Proceedings, August 1988, p. 397-406.

1989, Water Use in New York, 1985: U.S. Geological Survey Open-File Report 88727, Water Fact Sheet, 2 p.

Soren, Julian, 1988, Geologic and geohydrologic reconnaissance of Staten Island, New York: U.S. Geological Survey WaterResources Investigations Report 87-4048, $22 \mathrm{p}$.

Staubitz, W. W., and Zarriello, P. J., 1989, Hydrology of two headwater lakes in the Adirondack Mountains of New York: Canadian Journal of Fisheries and Aquatic Sciences, v. 46, no. 2, 1989, p. 268-276.

Tepper, D. H., 1989, Techniques for delineation of regional water-bearing zones in the Lockport dolomite, Niagara Falls area, New York [abst.], in Abstracts with Programs: Geological Society of America, Northeastern Section, p. 70, no. 14884.

Waller, R. M., 1988, Ground water and the rural homeowner: U.S. Geological Survey, $37 \mathrm{p}$.

Wexler, E. J., 1988, Ground-water flow and solute transport at a municipal landfill site on Long Island, New York-part 1, hydrogeology and water quality: U.S. Geological Survey Water-Resources Investigations Report 86-4070, 52 p.

1988, Ground-water flow and solute transport at a municipal landfill site on Long Island, New York-part 3, simulation of solute transport: U.S. Geological Survey Water-Resources Investigations Report 86-4207, 46 p.

Wexler, E. J., and Maus, P. E., 1988, Groundwater flow and solute transport at a municipal landfill site on Long Island, New York-part 2, simulation of groundwater flow: U.S. Geological Survey Water-Resources Investigations Report 86-4106, 44 p.

Wolcott, S. W., and Irwin, Don, 1988, Estimated thickness and potential well yield of stratified deposits in the upper Croton River basin, Westchester County, New York: U.S. Geological Survey WaterResources Investigations Report 87-4287, 3 sheets, scale 1:250,000.

Yager, R. M., and Bergeron, M. P., 1988, Nitrogen transport in a shallow outwash aquifer at Olean, Cattaraugus County, New York: U.S. Geological Survey WaterResources Investigations Report 87-4043, $51 \mathrm{p}$.

Zarriello, P. J., 1989, Simulated water-quality changes in detention basins [Abst.], in Roesner, L. A., Urbonas, Ben, and Sonnen, M. B., eds., Design of urban runoff quality controls: New York, American Society of Civil Engineers, p. 268-279.

Zarriello, P. J., and Surface, J. M., 1989, Simulation of changes in stormwater quality at four potential flow-attenuation sites in the Irondequoit Creek watershed, Monroe County, New York: U.S. Geological Survey Water Resources Investigations Report 86-4106, 52 p. 


\section{COOPERATING AGENCIES IN FISCAL YEAR 1989}

Chautauqua County Department of Planning $\mathcal{E}$ Development

Chenango County

City of Auburn

Cornell University

Cornell University, Department of Natural Resources

Cornell University, Electric Power Research Institute

Cortland County Planning Department

Dutchess County Environment Management Council

Federal Power Commission

Hudson River-Black River Regulating District

Long Island Regional Planning Board

Monroe County Department of Environmental Health

Nassau County Department of Health

Nassau County Department of Public Works

National Oceanic and Atmospheric Administration

New York City Department of Environmental Protection

New York State Department of Environmental Conservation - Division of Water

New York State Department of Environmental Conservation - Division of Fish $\mathcal{E}$ Wildlife

New York State Department of Transportation

New York State Power Authority

Onondaga County Department of Drainage

Onondaga County Water Authority

Orange County Water Authority 


\section{COOPERATING AGENCIES (continued)}

U.S. Fish $\mathcal{E}$ W ildlife Service - Montezuma Wildlife Refuge

Saratoga County Environmental Management Council

Seneca County Soil Conservation District

Suffolk County Department of Health Services

Suffolk County Water Authority

Tompkins County Department of Planning

Town of Amherst

Town of Brookhaven

Town of Cheektowaga

Temporary State Commission on Tug Hill

Ulster County

U.S. Army Corps of Engineers - Baltimore

U.S. Army Corps of Engineers - Buffalo District

U.S. Army Corps of Engineers - New York City

U.S. Army Corps of Engineers - Stream Gaging

U.S. Environmental Protection Agency - New York City

U.S. Environmental Protection Agency - Nuclear Energy

Regulating Commission, Corvallis, Oregon

U.S. Environmental Protection Agency - Washington

Village of Kiryas Joel

Village of Nyack

Westchester County Department of Health

Westchester County Department of Public Works 
SOURCES OF U.S. GEOLOGICAL SURVEY PUBLICATIONS

Current releases are described in a monthly pamphlet, "New Publications of the Geological Survey." To receive this publication monthly, write to

\author{
U.S. Geological Survey \\ 582 National Center \\ Reston, VA 22092
}

Professional Papers, Bulletins, Water Supply Papers, Techniques of Water Resources Investigations, and Open-file reports may be purchased as paper or microfiche copies from

\author{
U. S. Geological Survey \\ Books and Open-File Reports Section \\ Federal Center, Bldg. 41 \\ BOX 25425 \\ Denver, CO 80225
}

Map, benchmark, and aerial-photograph information is available from

National Cartographic Information Center

U.S. Geological Survey

507 National Center

Reston, VA 22092

Requests for miscellaneous water information and information on waterresources programs in other States may be referred to

\author{
U.S. Geological Survey \\ Water Resources Division \\ 440 National Center \\ Reston, VA 22092
}

The Geological Survey National Center maintains a library with an extensive earth-sciences collection. Local libraries may obtain books, periodicals, and maps through interlibrary loan by writing to

\title{
U.S. Geological Survey Library \\ 950 National Center \\ Reston, VA 22092
}




\title{
ADDITIONAL SOURCES OF INFORMATION \\ ON PROGRAMS IN NEW YORK
}

\author{
WATER \\ District Chief \\ U.S. Geological Survey \\ 343 James T. Foley Courthouse \\ Post Office Box 1669 \\ Albany, NY 12201 \\ Phone: (518) 472-3107

\begin{abstract}
National Mapping
National Cartographic

Information Center

U.S. Geological Survey

507 National Center

Reston, VA 22092
\end{abstract}

Phone: (703) 860-6045

\author{
Geology \\ Assistant Chief Geologist, \\ Eastern Region \\ U.S. Geological Survey \\ 953 National Center \\ Reston, VA 22092
}

Phone: (703) 860-6660

\section{General Information}

Public Inquiries Office

U.S. Geological Survey

503 National Center, Room 1C402

Reston, VA 22092

Phone: (703) 648-6892 